\title{
DIAGENESIS AND MASS TRANSFER BETWEEN PERMO-TRIASSIC SANDSTONES AND INTERBEDDED MUDSTONES, ULSTER BASIN
}

\author{
Wolela Ahmed*
}

School of Geosciences, Queen's University of Belfast, Belfast BT 7 1NN, Northern Ireland, UK

\author{
(Received December 8, 2000; revised April 26, 2002)
}

\begin{abstract}
Beds of siltstone, mudstone and shale are interbedded in the Permo-Triassic sandstones of the Ulster Basin, UK, at different stratigraphic levels. The paragenetic sequences of authigenic minerals both in the sandy and fine-grained sediments (mudstones and siltstones) indicate red bed diagenetic trend. Abundant authigenic quartz overgrowths and carbonate crystals observed near the sandstone-siltstone and sandstone-mudstone contacts, indicating that pore water and mass transfer from the fine-grained sediments to sandstone facies. The fine-grained sediments are the main source of ions for the authigenesis of quartz and feldspar overgrowths and carbonate precipitation. Mechanical compaction of fine-grained sediments, influx of gravity-driven acidic meteoric pore water, dehydration water, diffusion and convection are the most important means of mass transfer and pore water circulation. Pore water migration depends upon permeability distribution and pressure difference.
\end{abstract}

KEY WORDS: Permo-Triassic sandstones, Siltstone, Mudstone, Authigenic minerals, Diagenetic minerals, Ulster Basin

\section{INTRODUCTION}

The continental Permo-Triassic sandstones and the interbedded mudstones and siltstones of the Ulster Basin were considered to understand: (1) the main source of ions for the authigenesis of minerals; (2) the possibility of pore water and mass transfer between sandstones, mudstones and siltstones; and (3) the link between diagenetic minerals in sandstones and the interbedded mudstones and siltstones, particularly whether they follow the same diagenetic trend or different diagenetic trends. Such studies need identification of authigenic minerals to understand the major sinks for ions in the diagenetic environment. Scanning electron microscope (SEM) studies provide information to identify the most important sinks, and also to differentiate authigenic minerals from their corresponding or similar detrital minerals [1]. Essential information about the paragenetic sequence of the authigenic minerals could be obtained from SEM studies. Probe analysis gives a significant amount of information about the distribution, abundance, textural relationship, mineral composition, mineral transformation and zoning in cementing minerals [1].

X-Ray fluorescence (XRF) results provide bulk compositions of oxides in the rocks. Different types of mineral may contain the same types of oxides. For example $\mathrm{SiO}_{2}$ can be found in silicates, alumino-silicates, ferromagnesian minerals and phyllosilicates. The $\mathrm{SiO}_{2}$ content in the bulk composition might therefore come from different minerals. This is also true for $\mathrm{CaO}$ and $\mathrm{MgO}$, which are contributed from different minerals such as carbonates, ferromagnesian minerals and phyllosilicates. The XRF results in conjunction with scanning electron microscopy, electron microprobe and conventional petrographic microscopy can provide information about pore water and mass transfer between sandstones and fine-grained sediments (siltstones, mudstones and shales). 


\section{EXPERIMENTAL}

Borehole 4B (Lagan Valley) and outcrop sections at Cultra and Murlough Bay were logged, and samples were collected for laboratory analyses. The studied area is shown in Figure 1. In order to understand the most important contributors to the bulk composition, an integrated study has been carried out based on conventional petrographic microscope, electron microprobe, scanning electron microscope and X-ray fluorescence. The paragenetic sequences are reconstructed based on the textural relationship and superimposition of the authigenic minerals. The diagenetic minerals sequences for the sandstone were reconstructed from conventional petrographic microscopy, scanning electron microscopy and microprobe analysis, whilst the diagenetic mineral sequences for mudstones, siltstones and shales were established from scanning electron microscopy and electron microprobe.

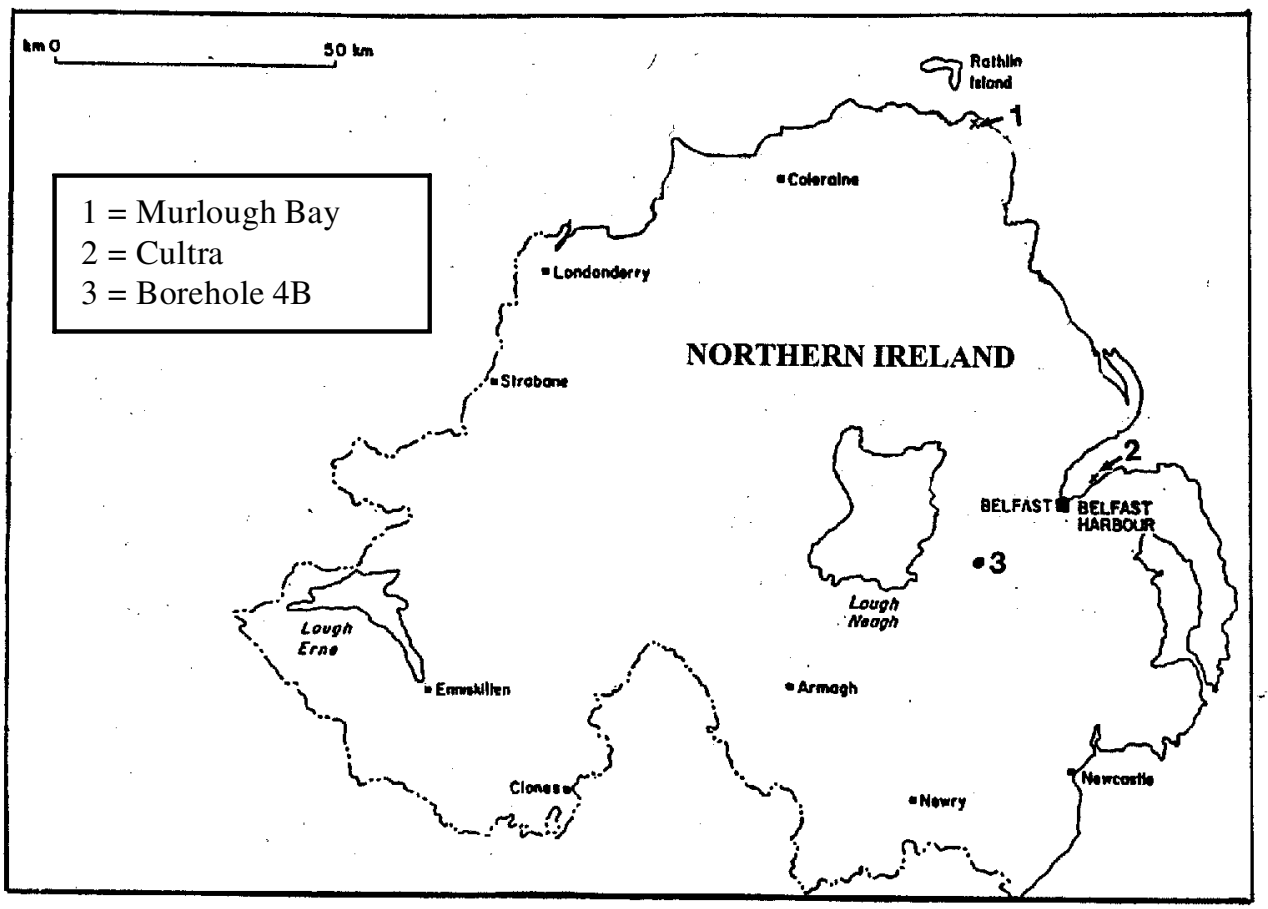

Figure 1. Location map of studied areas in the Ulster Basin.

Resin-impregnated thin sections were examined using transmitted light microscopy, and their modal composition was evaluated by counting 300 points [3]. Unpolished gold-coated chip samples were examined under a JEOL 6400 scanning electron microscope equipped with energy dispersive X-ray analysis (EDX) system with accelerating voltage of $10-15 \mathrm{kV}$, to identify the morphology of authigenic minerals, mineral composition and their textural relationships [1]. Polished carbon-coated chips and thin sections were examined under a JEOL 733 super probe with an accelerating voltage of $15 \mathrm{kV}$, to identify the mineralogical composition, textural relationships and zoning in authigenic minerals [2]. A ZAF software programme was used to calculate the weight percentage of oxides in each analysis. 
The abundance of authigenic quartz, carbonate cements, feldspars were counted using petrographic microscope and back-scattered electron microprobe. The textural and stratigraphic position of the authigenic minerals plus weight percentage oxide calculations, and X-ray florescence (XRF) were used to compare the diagenetic trends, pore water and mass transfer between sandstones and interbedded mudstones, siltstones and shales. Other than the PermoTriassic sandstones, studies were also carried out on sandstone beds that are interbedded within the Mercia Mudstone Group, which overlies the Permo-Triassic sandstones.

\section{RESULTS}

The following paragenetic mineral sequences were established from the textural relationships of the authigenic minerals in sandstones, siltstones and mudstones.

Precipitation of concretionary calcite $\left(\mathrm{CaCO}_{3}\right)$. This is one of the facies-related minerals in the sandy, silty and muddy facies. The distribution of concretionary calcite is more common in the sandy facies than in the muddy and silty facies. It exists as pore-filling cement without replacive characteristics. Small concretions of calcite were identified by SEM and microprobe studies. The concretions attain 10-15 $\mu \mathrm{m}$ diameter in the muddy facies (Figure 2a).

Mechanical compaction. Mechanical compaction took place at the early stage of diagenesis in both the muddy, silty and sandy facies. The presence of delicate grain coatings after dissolution of grains indicate that mechanical compaction took place before the grain coatings were precipitated.

Illite-smectite/hematite precipitation. These are among the earliest authigenic minerals in both the muddy, silty and sandy facies. Dissolution of unstable ferromagnesian minerals, feldspars and micas was the most likely source for the authigenesis of these minerals. Illite-smectite exists in the form of grain coating, pore-lining and pore-filling cements (Figure 2a-d). Microprobe analyses of illite in the muddy and silty facies have average composition of $49.58 \% \mathrm{SiO}_{2}$, $13.73 \% \mathrm{Al}_{2} \mathrm{O}_{3}$ and $10.25 \% \mathrm{~K}_{2} \mathrm{O}$, whereas illite in the sandy facies yielded mean values $61.44 \%$ $\mathrm{SiO}_{2}, 15.21 \% \mathrm{Al}_{2} \mathrm{O}_{3}$ and $14.00 \% \mathrm{~K}_{2} \mathrm{O}$. SEM and probe analysis confirmed the presence of minor amounts of grain coating chlorite in the studied sandstone, mudstone and siltstone samples (Figure 2a). Except for minor amounts of authigenic illite and illite-smectite the shaly facies is dominated by detrital illite and smectite.

Authigenesis of $\mathrm{K}$-feldspar $\left(\mathrm{KAlSi}_{3} \mathrm{O}_{8}\right)$ and albite $\left(\mathrm{NaAlSi}_{3} \mathrm{O}_{8}\right)$. SEM and probe analyses indicate that feldspar overgrowths and crystals are widely distributed throughout the sandstones, and the interbedded siltstones and mudstones (Figure 2c). More feldspar overgrowths and crystals are distributed in the sandy facies than in the silty and muddy facies. Euhedral K-feldspar crystals range from 5-10 $\mu \mathrm{m}$ across in the muddy facies (Figure $2 \mathrm{~d}$ ), whereas the euhedral crystals in the sandy facies range from 10-40 $\mu \mathrm{m}$ across. Microprobe weight percentage calculations on authigenic crystals of $\mathrm{K}$-feldspar in the silty and muddy facies revealed average compositions of 63.49\% $\mathrm{SiO}_{2}, 20.52 \% \mathrm{Al}_{2} \mathrm{O}_{3}, 15.60 \% \mathrm{~K}_{2} \mathrm{O}$ and $0.5 \% \mathrm{Na}_{2} \mathrm{O}$, whereas calculations on authigenic $\mathrm{K}$-feldspar in the sandy facies revealed average compositions of $63.96 \% \mathrm{SiO}_{2}, 19.10 \% \mathrm{Al}_{2} \mathrm{O}_{3}$ and $16.94 \% \mathrm{~K}_{2} \mathrm{O}$. 

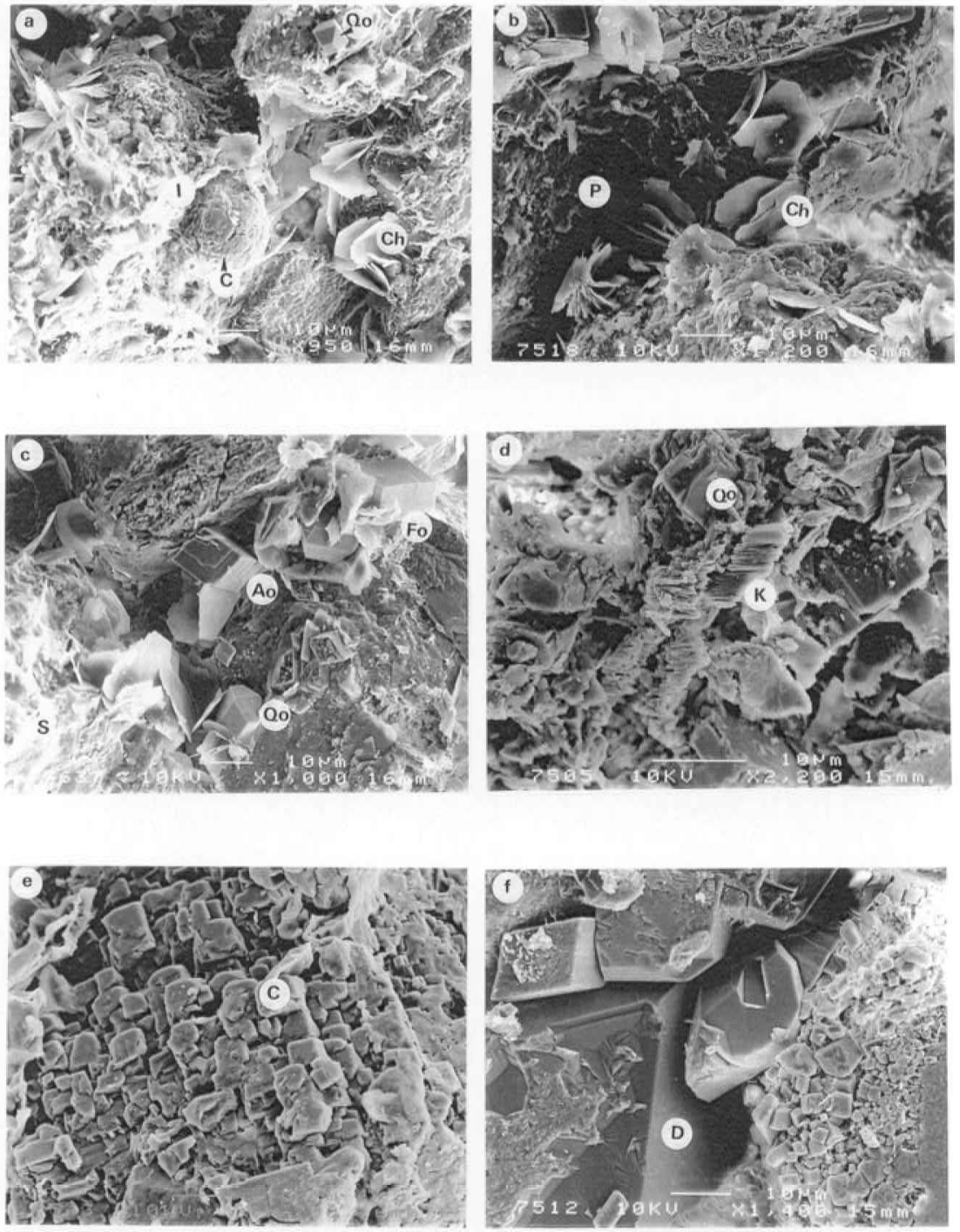

Figure 2. (a) SEM photomicrograph showing concretionary calcite (C), grain coating illite (I), chlorite (Ch) and quartz overgrowths (Qo), Triassic sandstone, 4B-17, mudstone sample, 30 meter depth, borehole 4B (Lagan Valley), Ulster Basin (scale bar 10 microns). (b) SEM photomicrograph showing pore-filling and grain coating chlorite $(\mathrm{Ch})$, and porosity $(\mathrm{P})$, Triassic sandstone, $\mathrm{CU}-10$, outcrop mudstone sample, Cultra (Co. Down), Ulster Basin (scale bar 10 microns). (c) SEM photomicrograph showing grain coating smectite (S), albite overgrowths (Ao), K-feldspar overgrowths (Fo), and incipient quartz overgrowts (Qo), Triassic sandstone, 4B-7, mudstone sample, 30 meter depth, borehole 4B (Lagan Valley), Ulster Basin (scale bar 10 microns). (d) SEM photomicrograph showing quartz overgrowths (Qo), and pore-filling kaolinite (K), Triassic sandstone, 4B-19, mudstone sample, 66 meter depth, borehole 4B (Lagan Valley), Ulster Basin (scale bar 10 microns). (e) SEM photomicrograph showing extensive precipitation of calcite (C) crystals in sandy facies that interbedded within the Mercia Mudstone Group, MM-2, outcrop sample, Mulough Bay, Ulster Basin (scale bar 10 microns). (f) SEM photomicrograph showing extensive dolomite crystals (D) precipitation in the sandy facies that interbedded within the Mercia Mudstone Group, MM-8, outcrop sample, Murlough Bay, Ulster Basin (scale bar 10 microns). 
Authigenic albite crystals are observed in both facies from borehole 4B-1 (Lagan Valley) and from the Scrabo Hill Quarry (Figure 2c). Microprobe weight percentage calculations for albite crystals in the silty and muddy facies yield average of $70.93 \% \mathrm{SiO}_{2}, 19.01 \% \mathrm{Al}_{2} \mathrm{O}_{3}$ and $10 \% \mathrm{Na}_{2} \mathrm{O}$, whilst authigenic albite crystals in the sandy facies have average compositions of $65.89 \% \mathrm{SiO}_{2}, 21.56 \% \mathrm{Al}_{2} \mathrm{O}_{3}, 12.52 \% \mathrm{NaO}_{2}$. Authigenic $\mathrm{K}$-feldspar or albite overgrowths and crystals were not observed in the studied shaly facies. Some of the authigenic feldspars were replaced by late stage carbonate cements, indicating that the precipitation of authigenic feldspars pre-dated carbonate cementation (Figure 2e, 2f). SEM studies, EDX identification and probe analysis confirmed that the most important sink for silicon, potassium, aluminium and sodium ions in the diagenetic environment is K-feldspar and albite.

$\mathrm{XRF}$ data for the Murlough Bay section (Figure 4) revealed that $\mathrm{K}_{2} \mathrm{O}$ concentration is high (6-7\%) in the upper part of the Mercia Mudstone Group, whereas the concentration decreases towards the mudstone-sandstone contact $(2 \%)$. Below the mudstone-sandstone contact, in the sandy facies the concentration $\mathrm{K}_{2} \mathrm{O}$ increases from 2 to $6 \%$, but it shows a sharp drop in concentration in the middle part of the sandstone from 6 to $2 \%$, and again increases towards the sandstone-breccia contact up to $7 \%$. The $\mathrm{Al}_{2} \mathrm{O}_{3}$ plot for the Murlough Bay (Figure 3) also indicates that the upper part of the Mercia Mudstone Group shows a high concentration of up to $15 \%$ and decreases near the mudstone-sandstone contact, and again increases in the sandy facies, and remaining constant between 5 and $10 \%$ within the sandy facies. The $\mathrm{Al}_{2} \mathrm{O}_{3}$ content in the sandy breccia decreases from $10 \%$ at the base to $2 \%$ near the sandy breccia-sandstone contact. The concentration of $\mathrm{Al}_{2} \mathrm{O}_{3}$ increases up to $10 \%$ in the sandy facies near the sandstone-sandy breccia contact (Figure 3).

XRF plot for the Cultra section (Figure 4) shows that the concentration of $\mathrm{K}_{2} \mathrm{O}$ fluctuates slightly in the silty and muddy facies from 2 to $3 \%$. In the sandy facies the concentration of $\mathrm{K}_{2} \mathrm{O}$ fluctuates between 2 and 5\%, but remains nearly constant between 3 and 4\%. The concentration of $\mathrm{Al}_{2} \mathrm{O}_{3}$ varies between 5 and $10 \%$ in the silty and muddy facies. In the sandy facies, the concentration of $\mathrm{Al}_{2} \mathrm{O}_{3}$ varies between 2 and $10 \%$, but is generally 7 to $10 \%$. Microprobe analyses of authigenic K-feldspar and albite are given in Table 1 and 2.

Table 1. Microprobe average analyses (\% composition) of authigenic K-feldspar in sandstone and interbedded siltstones and mudstones (Permo-Triassic sandstones).

\begin{tabular}{|l|c|c|c|c|c|c|}
\hline Location & Sample type & Sample No. & $\mathrm{SiO}_{2}$ & $\mathrm{Al}_{2} \mathrm{O}_{3}$ & $\mathrm{Na}_{2} \mathrm{O}$ & $\mathrm{K}_{2} \mathrm{O}$ \\
\hline Lagan Valley & Mudstone & 4B-1 & 63.49 & 24.24 & 0.00 & 12.28 \\
\hline Lagan Valley & Mudstone & $4 \mathrm{~B}-7$ & 63.84 & 19.36 & 0.00 & 16.80 \\
\hline Lagan Valley & Mudstone & $4 \mathrm{~B}-19$ & 63.38 & 18.81 & 0.00 & 17.80 \\
\hline Scrabo & Siltstone & NI-05 & 62.19 & 21.21 & 1.52 & 15.08 \\
\hline Scrabo & Sandstone & NI-06 & 64.20 & 19.54 & 0.43 & 15.08 \\
\hline Lagan Valley & Sandstone & 4B-9 & 63.61 & 19.04 & 1.15 & 16.19 \\
\hline Lagan Valley & Sandstone & 4B-11 & 63.52 & 19.27 & 0.21 & 16.99 \\
\hline Lagan Valley & Sandstone & 4B-13 & 63.93 & 19.18 & 0.49 & 16.40 \\
\hline Lagan Valley & Sandstone & 4B-27 & 63.99 & 19.59 & 0.73 & 16.18 \\
\hline Lagan Valley & Mudstone & 4B-31 & 63.99 & 18.99 & 0.98 & 16.03 \\
\hline Lagan Valley & Sandstone & 4B-37 & 63.72 & 19.29 & 0.32 & 16.66 \\
\hline
\end{tabular}


Table 2. Microprobe average analyses (\% composition) of authigenic albite in sandstones and interbedded siltstones and mudstones (Permo-Triassic sandstones, Ulster Basin).

\begin{tabular}{|c|c|c|c|c|c|c|}
\hline Location & Sample type & Sample No. & $\mathrm{SiO}_{2}$ & $\mathrm{Al}_{2} \mathrm{O}_{3}$ & $\mathrm{Na}_{2} \mathrm{O}$ & $\mathrm{K}_{2} \mathrm{O}$ \\
\hline Scrabo & Silstone & NI-05 & 75.05 & 15.62 & 9.32 & 0.00 \\
\hline Lagan Valley & Mudstone & $4 \mathrm{~B}-1$ & 68.65 & 20.42 & 10.91 & 0.00 \\
\hline Lagan Valley & Mudstone & $4 \mathrm{~B}-7$ & 69.08 & 21.01 & 9.91 & 0.00 \\
\hline Lagan Valley & Sandstone & $4 \mathrm{~B}-37$ & 65.89 & 21.56 & 12.55 & 0.00 \\
\hline
\end{tabular}
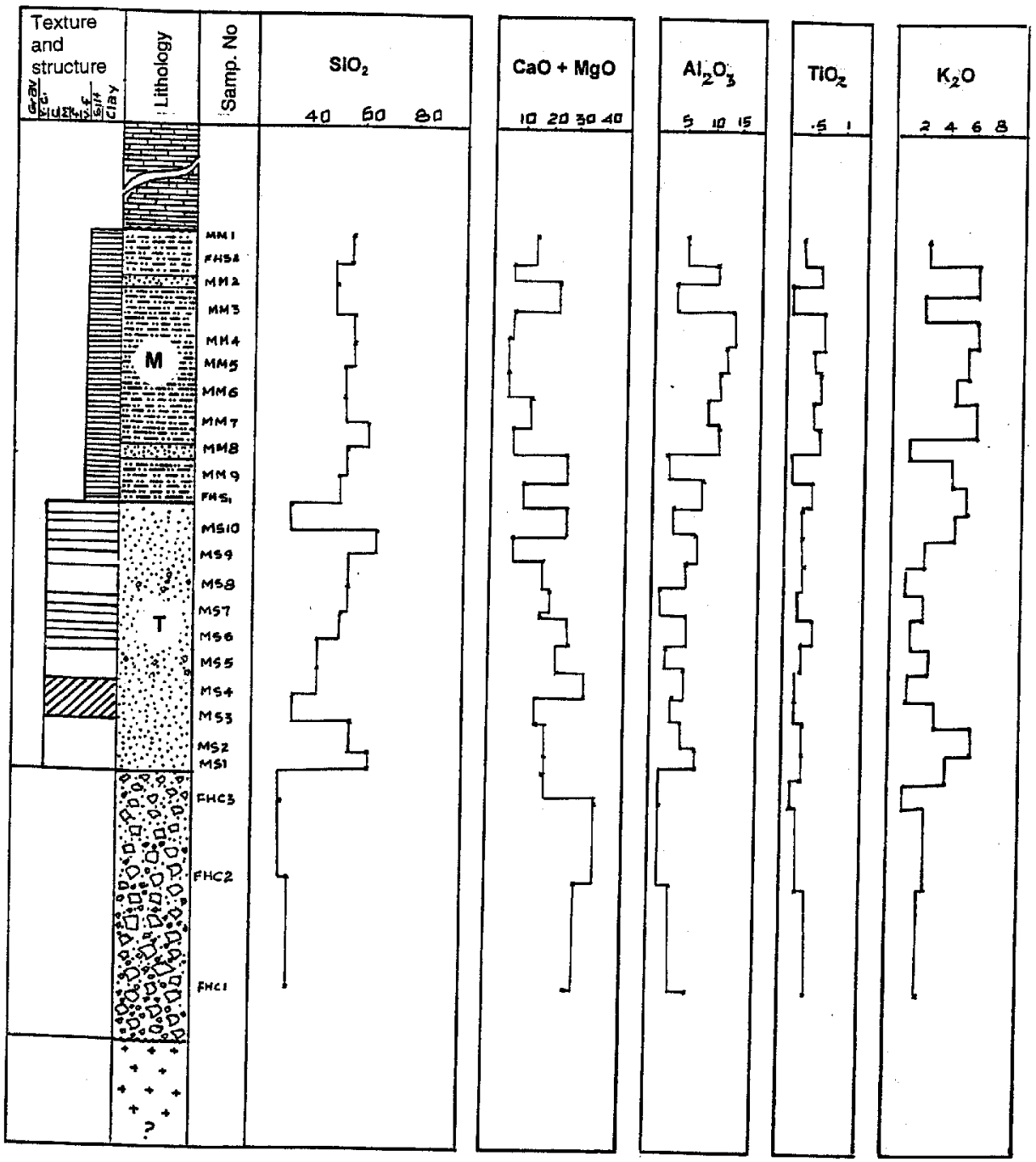

Figure 3. XRF data plot for major oxides, Murlough Bay, Ulster Basin. $\mathrm{T}=$ Triassic, $\mathrm{M}=$ Mercia Mudstone. 
Authigenesis of quartz. Quartz overgrowths are predominantly observed in the sandy facies, rather than in the silty and muddy facies (Figure 2a, c, d; 5a-d). This might be related to a higher permeability in the sandy facies. Partial overgrowths, complete overgrowths, euhedral crystals are less common in the muddy facies compared to the sandy facies. Authigenic quartz is totally absent in the studied shaly facies. SEM studies revealed that the quartz crystals are smaller in the muddy facies, ranging from 5-20 $\mu \mathrm{m}$ across, whilst the quartz overgrowths in the sandy facies range from 5 to $60 \mu \mathrm{m}$ across and 10 to $100 \mu \mathrm{m}$ in length.
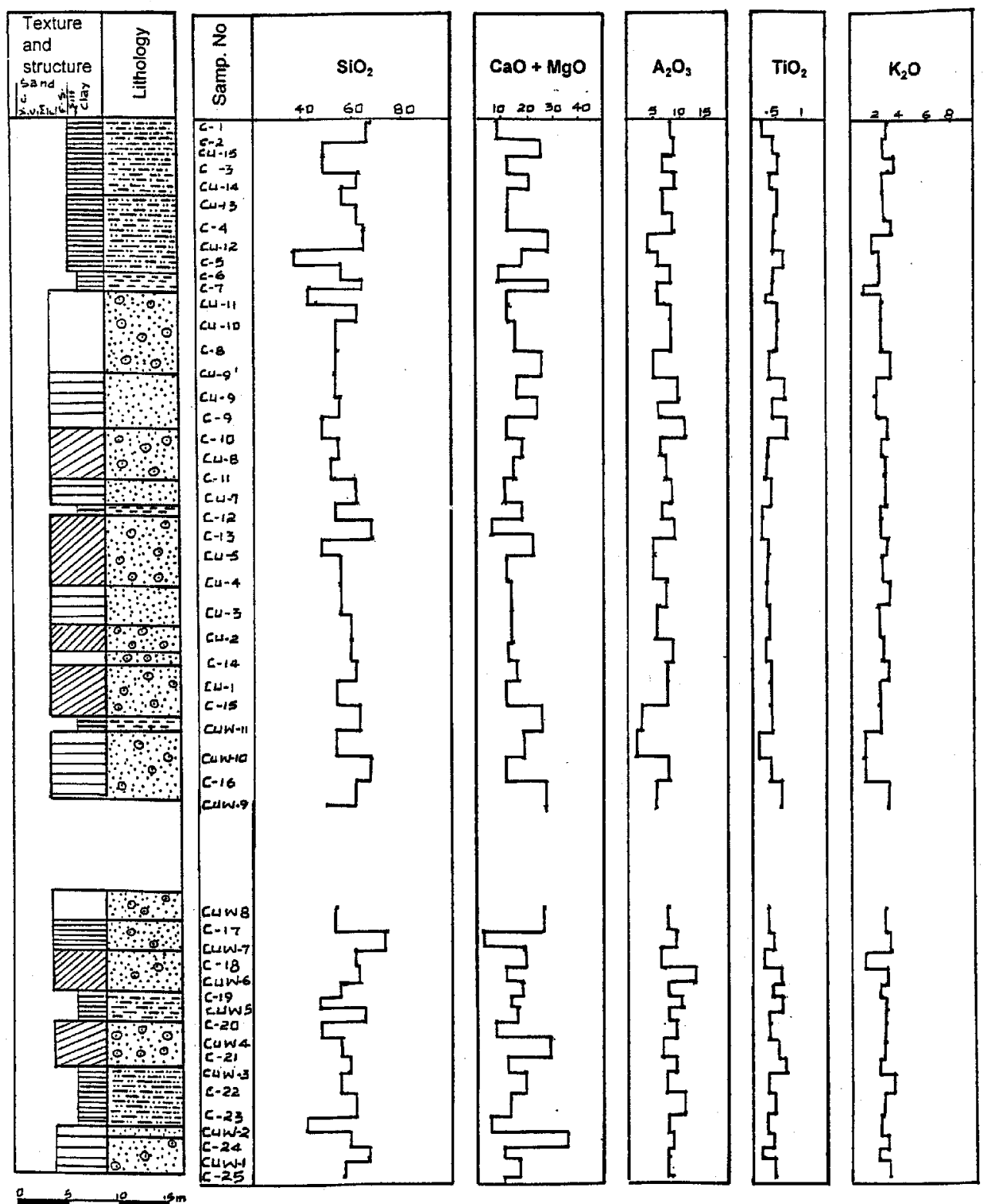

Figure 4. XRF data plot for major oxides, Cultra, Ulster Basin. 
SEM and microprobe studies show abundant quartz crystals in some of the sandy facies near the sandstone-mudstone contact (Figure $5 \mathrm{a}$ and $\mathrm{b}$ ). The abundance of the quartz crystals decreases away from the mudstone-sandstone contact (Figure 5c). The distribution of abundant quartz crystals near the mudstone-sandstone contact and a decrease in their concentration away from the contact is possible evidence for pore water and mass transfer from the silty muddy facies to the sandy facies.

The XRF data for $\mathrm{SiO}_{2}$ in the Cultra section (Figure 4) indicates mass transfer from the muddy facies to the sandy facies. There is a general decreasing trend in the content of $\mathrm{SiO}_{2}$ from the upper part of the section towards the mudstone-sandstone contact from 70 to $35 \%$. The concentration increases from 35 to $60 \%$ in the sandy facies below the mudstone-sandstone contact. In the middle part of the sandy facies the concentration remains constant at about $40 \%$. The sharp change in the concentration of $\mathrm{SiO}_{2}$ from the muddy facies towards the sandy facies is also a good indicator of mass transfer from the muddy facies to the sandy facies. This shows that the interbedded mudstones and siltstones could be one of the possible sources for the authigenic silica in the sandy facies. Point counting of quartz crystals has been incorporated with the XRF results given in (Figure 6).

XRF plot data for the Murlough Bay section (Figure 3) indicates that the concentration of $\mathrm{SiO}_{2}$ in the Mercia Mudstone Group decreases from 55 to $40 \%$ towards the mudstone-sandstone contact. The concentration increases from the mudstone-sandstone contact towards the middle part of the sandy facies from 40 to $70 \%$. The concentration of the silicon oxides decreases from the base of the sandy breccia towards the sandy facies from 40 to $10 \%$, and increase to $70 \%$ in the sandy facies. This possibly indicates that the silica budget might have come from two different sources, i.e. the sandy breccia and the overlying Mercia Mudstone Group. Quartz overgrowths (point counting) and XRF data for borehole 4B (Figure 7) indicate that more authigenic quartz is observed in some of the sandy facies near the siltstone-sandstone and mudstone-sandstone contact. Similar conclusion was also drawn by Houseknecht [4]. In that study Houseknecht [4] compared fine-grained sandstone facies to coarse-grained sandstone facies by plotting quartz cement/detrital quartz versus overlapping quartz/detrital quartz. Any sample that plots below the 1:1 ratio (mass balance line) is considered to be a silica importer, and any sample that plots above the 1:1 line is considered to be a silica exporter.

Carbonate cementation. The sandstones and the interbedded siltstone and mudstones facies contain varieties of carbonate cements (calcite, ferroan calcite, dolomite, ferroan dolomite and ankerite). Volumetrically, calcite and dolomite cements are the predominant carbonate cements in the muddy, silty and sandy facies. Calcite cement exists in two forms, as euhedral crystals and poikilotopic cement. The calcite crystals in the silty and muddy facies range from $1-10 \mu \mathrm{m}$ across (Figure 2e and f), whilst the calcite crystals in the sandy facies vary from 5-30 $\mu \mathrm{m}$ across. Minor amounts of manganese recorded in the calcite cement. Microprobe analyses of calcite cement in the muddy and silty facies revealed an average $\mathrm{Mn} / \mathrm{Ca}$ ratio of 0.041 . Ferroan calcite in the muddy and silty facies revealed an average $\mathrm{Fe} / \mathrm{Ca}$ ratio of 0.292 . Calcite in the sandy facies has $\mathrm{Mn} / \mathrm{Ca}$ ratio of 0.183 .

Dolomite exists in euhedral and microcrystalline form in the muddy, silty and sandy facies (Figure 2f). The dolomite crystals in the silty and muddy facies range from $2-10 \mu \mathrm{m}$ across, whilst they range from 5-40 $\mu \mathrm{m}$ across in the sandy facies. Microprobe analyses of dolomite in the silty and muddy facies revealed an average $\mathrm{Mg} / \mathrm{Ca}$ ratio of 0.655 , whereas microprobe analyses of dolomite cement in the sandy facies revealed an average $\mathrm{Mg} / \mathrm{Ca}$ ratio of 0.564 . 

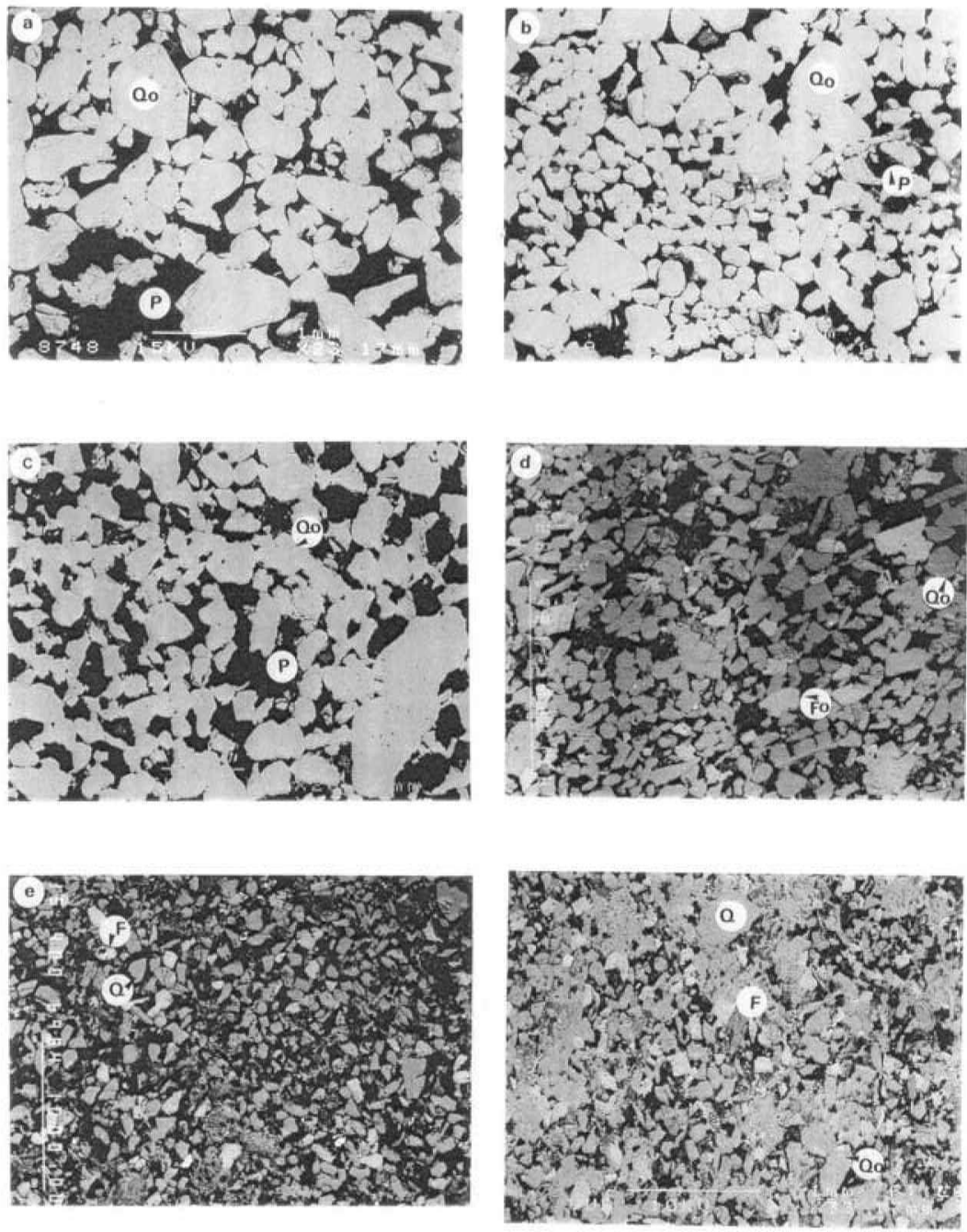

Figure 5. (a) Back-scattered electron photomicrograph showing extensive precipitation of authigenic quartz crystals $(\mathrm{Qo})$ and pore spaces $(\mathrm{P})$ in the sandy facies near the mudstone-sandstone contact, Triassic sandstone, 4B-3, $18 \mathrm{~m}$ depth, borehole 4B, Lagan Valley, Ulster Basin (scale $1 \mathrm{~mm}$ ). (b) Back-scattered Photomicrograph showing extensive precipitation of authigenic quartz crystals (Qo) and porosity (P), Note the corroded crystals, Triassic sandstone, 4B-3, $18 \mathrm{~m}$ depth, borehole 4B (Lagan Valley), Ulster Basin (scale bar $1 \mathrm{~mm}$ ). (c) Back-scattered photomicrograph showing extensive corroded quartz overgrowths (Qo) by late stage carbonate cements and porosity (P), Triassic sandstone, 4B-21, $72 \mathrm{~m}$ depth, borehole 4B (Lagan Valley), Ulster Basin (scale bar $1 \mathrm{~mm}$ ). (d) Back-scattered photomicrograph showing feldspar overgrowths (Fo), quartz overgrowths (Qo) and pore spaces, Triassic mudstone, 4B-11, $42 \mathrm{~m}$ depth, borehole 4B (Lagan Valley) Ulster Basin (scale bar 1000microns). (e) Back-scattered photomicrograph showing feldspar grains (F) and quartz grain (Q), Triassic siltstone, 4B-29, borehole 4B (Lagan Valley) Ulster Basin (scale bar 1000 microns). (f) Back-scattered photomicrograph showing extensive dissolution of feldspar (F), quartz grains (Q) and quartz crystals (Qo), Triassic sandstone, 4B-11, $42 \mathrm{~m}$ depth, borehole 4B (Lagan Valley), Ulster Basin (scale bar 1mm). 
Wolela Ahmed
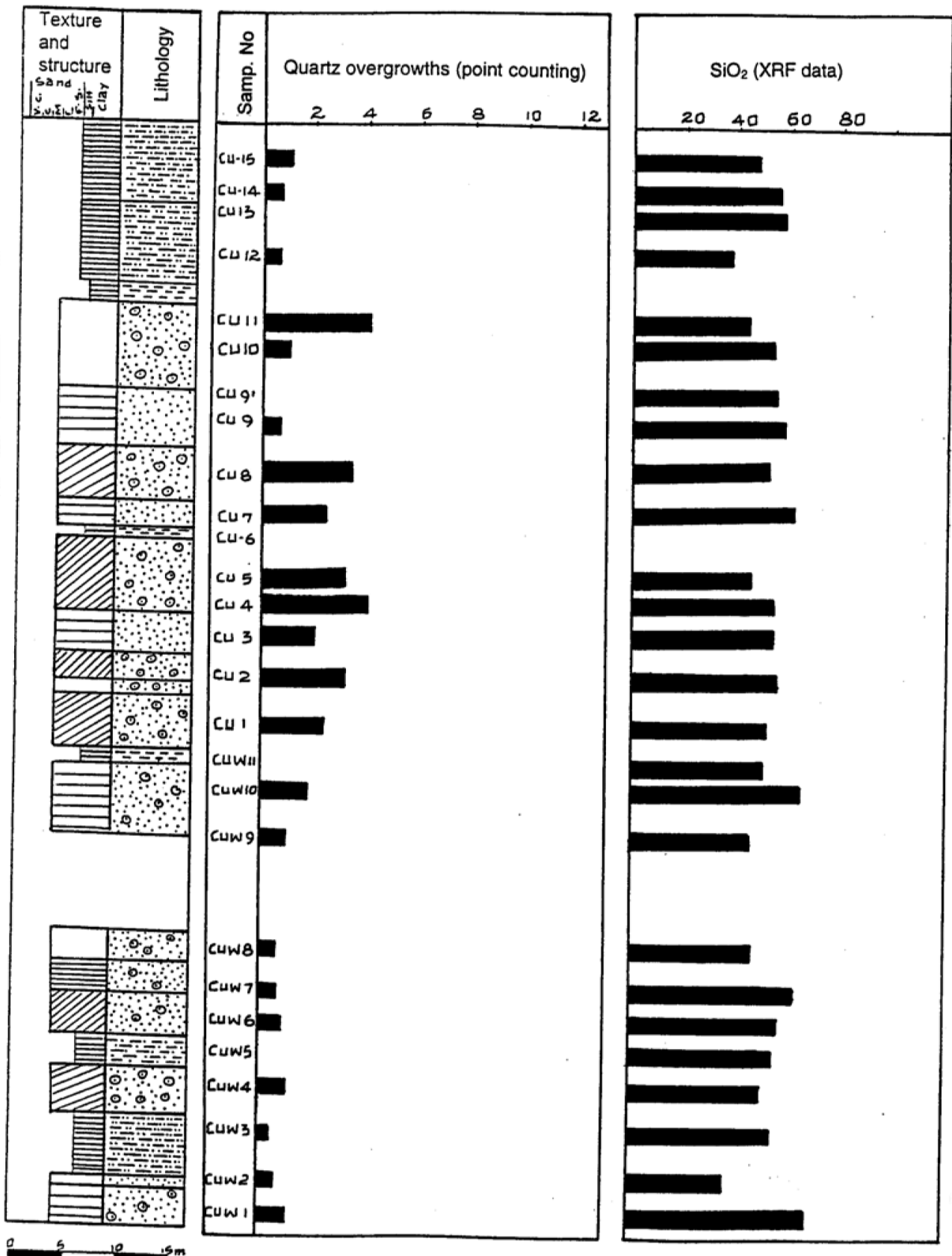

Figure 6. Point counting quartz overgrowths contents and silicon oxide (XRF) data, Cultra, Ulster Basin. 

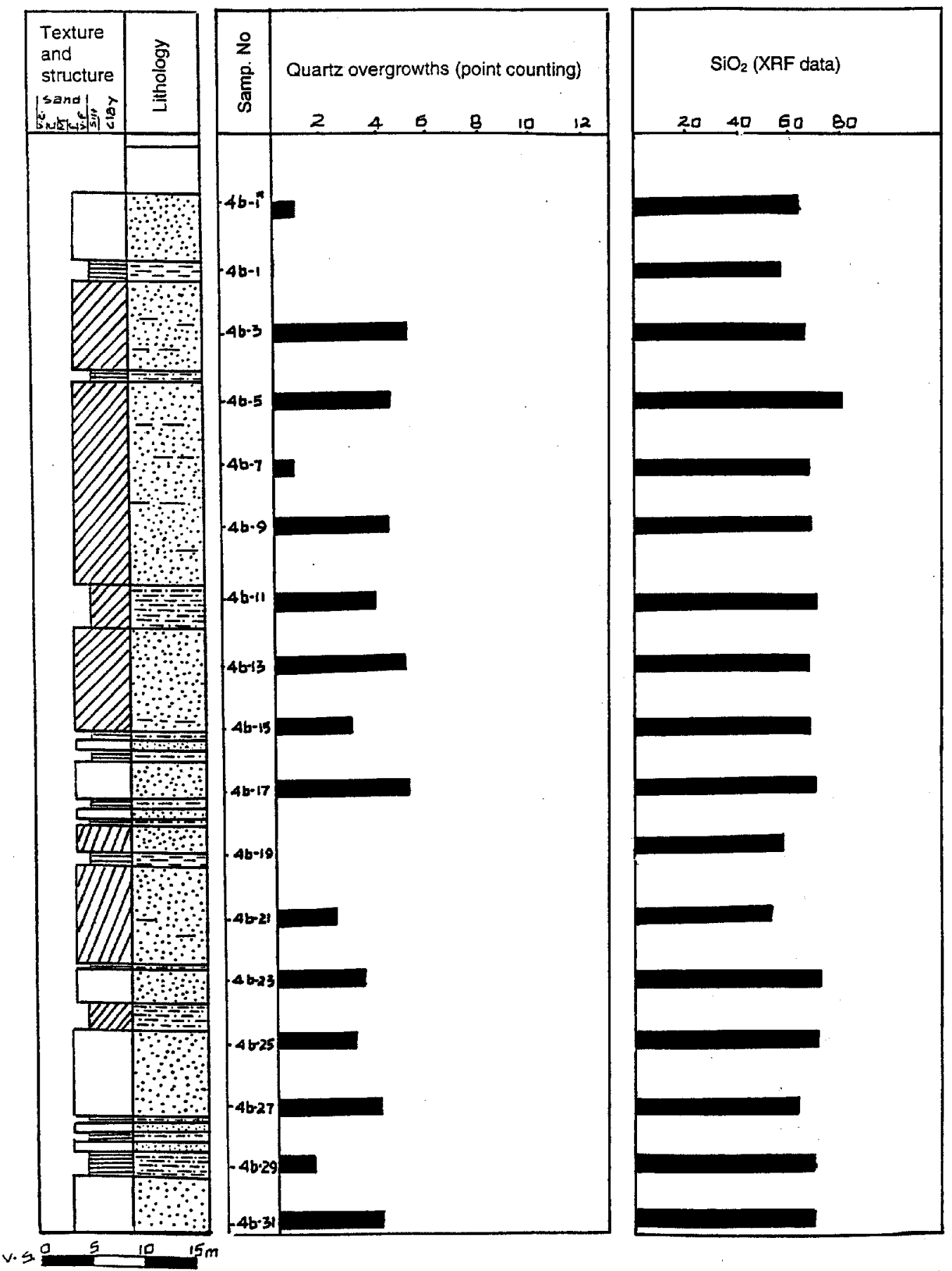

Figure 7. Point counting quartz overgrowths content and silicon oxide (XRF) data, borehole 4B, Lagan Valley, Ulster Basin. 
Table 3. Microprobe analyses (\% composition) of dolomite and ferroan dolomite cements (Permo-Triassic sandstones, Ulster Basin).

\begin{tabular}{|c|c|c|c|c|c|c|c|c|}
\hline Sample No. & Location & Lithology & $\mathrm{SiO}_{2}$ & $\mathrm{Al}_{2} \mathrm{O}_{3}$ & $\mathrm{Fe}_{2} \mathrm{O}_{3}$ & $\mathrm{CaO}$ & $\mathrm{MgO}$ & $\mathrm{MnO}$ \\
\hline 4B-1 & Lagan Valley & Mudrock & 0.358 & & & 32.771 & 24.502 & \\
\hline \multirow[t]{6}{*}{ 4B-19 } & Lagan Valley & Mudrock & & & & 33.416 & 23.168 & \\
\hline & & & 0.379 & & & 33.561 & 21.169 & \\
\hline & & & 0.266 & & & 29.651 & 18.948 & 0.7 \\
\hline & & & & & 1.934 & 29.384 & 15.284 & 0.72 \\
\hline & & & & & 3.912 & 36.992 & 16.453 & \\
\hline & & & & & 0.586 & 24.694 & 13.79 & 0.748 \\
\hline \multirow[t]{8}{*}{ 4B-9 } & Lagan Valley & Sandstone & & & & 32.406 & 21.933 & \\
\hline & & & 0.394 & & & 26.938 & 13.263 & 0.514 \\
\hline & & & & & & 26.279 & 15.455 & 0.812 \\
\hline & & & 0.672 & & & 26.707 & 15.08 & 0.936 \\
\hline & & & & & & 27.507 & 13.396 & 0.662 \\
\hline & & & & 0.625 & & 27.258 & 15.205 & 0.801 \\
\hline & & & & & & 27.338 & 15.205 & 0.733 \\
\hline & & & & & & 31.387 & 19.775 & \\
\hline \multirow[t]{5}{*}{ 4B-11 } & Lagan Valley & Sandstone & & & & 31.282 & 19.658 & \\
\hline & & & 0.329 & & & 31.536 & 19.344 & \\
\hline & & & & & & 28.522 & 16.642 & 0.827 \\
\hline & & & 0.487 & & & 26.621 & 16.338 & 0.597 \\
\hline & & & & & 3.943 & 28.692 & 16.351 & 0.782 \\
\hline \multirow[t]{6}{*}{ 4B-13 } & Lagan Valley & Sandstone & 0.374 & & 3.011 & 26.821 & 15.663 & 0.524 \\
\hline & & & 0.313 & & & 32.445 & 17.131 & 1.076 \\
\hline & & & & & 3.843 & 27.145 & 14.959 & 0.821 \\
\hline & & & 0.991 & & & 30.187 & 15.842 & 0.435 \\
\hline & & & & & 7.877 & 28.227 & 15.67 & \\
\hline & & & & & 1.934 & 27.384 & 15.283 & 0.72 \\
\hline \multirow[t]{3}{*}{ 4B-27 } & Lagan Valley & Sandstone & 1.272 & & & 26.216 & 15.18 & 0.909 \\
\hline & & & & & 0.977 & 29.434 & 14.227 & 1.211 \\
\hline & & & 1.754 & & 3.662 & 28.02 & 14.043 & 0.616 \\
\hline \multirow[t]{6}{*}{ 4B-37 } & Lagan Valley & Sandstone & 2.228 & & & 36.193 & 17.266 & 1.092 \\
\hline & & & & & & 28.153 & 15.761 & 1.149 \\
\hline & & & & & & 29.848 & 15.493 & \\
\hline & & & 0.713 & & 5.673 & 28.366 & 14.345 & 0.556 \\
\hline & & & & & & 30.966 & 15.853 & 0.614 \\
\hline & & & & & & 31.002 & 15.694 & 0.654 \\
\hline
\end{tabular}


Table 4. Microprobe analyses (\% composition) of calcite and ferroan calcite cements (Permo-Triassic sandstones, Ulster Basin).

\begin{tabular}{|c|c|c|c|c|c|c|c|}
\hline Sample No. & Location & Lithology & $\mathrm{SiO}_{2}$ & $\mathrm{Al}_{2} \mathrm{O}_{3}$ & $\mathrm{Fe}_{2} \mathrm{O}_{3}$ & $\mathrm{CaO}$ & $\mathrm{MnO}$ \\
\hline \multirow[t]{2}{*}{\begin{tabular}{|l|}
$\mathrm{CU}-7$ \\
\end{tabular}} & Cultra & Mudrock & 1.402 & & 0.66 & 43.502 & \\
\hline & & & & & & 47.902 & \\
\hline \multirow[t]{3}{*}{ CU-10 } & Cultra & Siltstone & 2.241 & & & 44.206 & \\
\hline & & & 0.478 & & & 56.405 & \\
\hline & & & 0.598 & & & 51.402 & \\
\hline \multirow[t]{5}{*}{$\mathrm{T}-06$} & Tyrone & Mudrock & 5.166 & 1.169 & \begin{tabular}{|l|}
1.669 \\
\end{tabular} & 42.568 & \\
\hline & & & & & & 52.445 & \\
\hline & Dorlis & Siltstone & & & & 50.01 & \\
\hline & & & 5.275 & 2.124 & 1.043 & 41.014 & \\
\hline & & & & & & 54.979 & \\
\hline \multirow[t]{4}{*}{ NI-18 } & Dorlis & Sandstone & & & & 54.408 & \\
\hline & & & & & 1.032 & 49.707 & \\
\hline & & & & & & 53.537 & \\
\hline & & & & & & 51.042 & \\
\hline \multirow[t]{4}{*}{ 4B-27 } & Lagan Valley & Sandstone & 0.404 & & & 49.383 & 0.961 \\
\hline & & & & & & 49.049 & 0.914 \\
\hline & & & & & & 49.972 & 0.773 \\
\hline & & & & & & 49.951 & 0.626 \\
\hline \multirow[t]{4}{*}{ 4B-13 } & Lagan Valley & Sandstone & & & & 49.836 & 1.082 \\
\hline & & & & & & 52.378 & 0.874 \\
\hline & & & & & & 52.384 & 1.319 \\
\hline & & & & & 0.526 & 52.316 & \\
\hline
\end{tabular}

Microprobe analyses of ferroan dolomite and ankerite cements in the silty and muddy facies revealed an average $\mathrm{Fe} / \mathrm{Ca}$ ratio of $0.088, \mathrm{Mg} / \mathrm{Ca}$ ratio of 0.478 and $\mathrm{Mn} / \mathrm{Ca}$ ratio of 0.017 . Microprobe analyses on the ferroan dolomite and ankerite in the sandstone facies revealed an average $\mathrm{Fe} / \mathrm{Ca}$ ratio of $0.122, \mathrm{Mg} / \mathrm{Ca}$ ratio of 0.540 and $\mathrm{Mn} / \mathrm{Ca}$ ratio of 0.024 . Microprobe analyses of carbonate cements are given in Table 3 and 4. Table 3 and 4 also show zoning in cementing minerals.

XRF data for Murlough Bay (Figure 3 and 8) show that in the upper part of the Mercia Mudstone Group, with the exception of the interbedded sandstones, the concentration of the $\mathrm{CaO}$ and $\mathrm{MgO}$ is low (5 to $15 \%$ ), but towards the mudstone-sandstone contact the concentration of $\mathrm{CaO}$ and $\mathrm{MgO}$ gradually increases. The concentration of $\mathrm{CaO}$ and $\mathrm{MgO}$ increases below the mudstone-sandstone contact in the sandy facies up to $25 \%$. The concentration of $\mathrm{CaO}$ and $\mathrm{MgO}$ also increases from the base of the sandy breccia contact towards the sandstone facies. XRF data (Figure 3 and 8) also indicate a high concentration of $\mathrm{CaO}$ and $\mathrm{MgO}$ of up to $30.33 \%$ near the sandstone-sandy breccia contact. This is consistent with SEM results (Figure 2e and f).

XRF data for the Cultra section (Figure 4) shows that the concentration of the $\mathrm{CaO}$ and $\mathrm{MgO}$ is high in the upper part of the muddy and silty facies, up to $25 \%$. The concentration decreases from the silty facies towards the muddy facies and increases towards the mudstone-sandstone contacts. The Cultra sandstone is characterized by high concentrations of $\mathrm{CaO}$ and $\mathrm{MgO}$ near the mudstone-sandstone contact. The $\mathrm{CaO}$ and $\mathrm{MgO}$ content increases up to $27 \%$ in the sandy facies near the sandstone-mudstone contact. In the sandy facies the $\mathrm{CaO}$ and $\mathrm{MgO}$ concentration varies from $5-20 \%$, but is generally $10-20 \%$. Point counting confirmed that the carbonate cements account for up to $40.6 \%$ in the sandy facies near the sandstone-mudstone contact. 

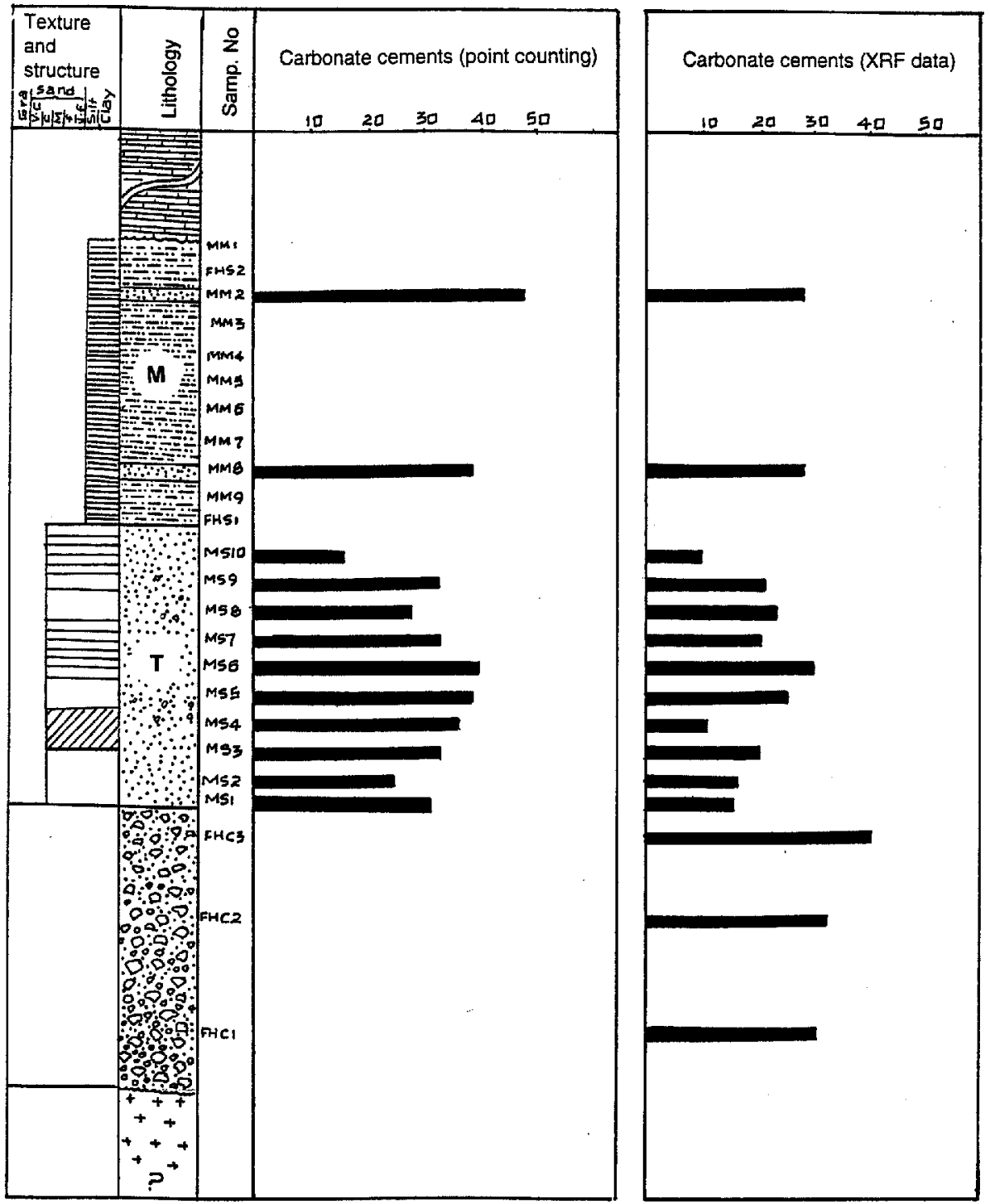

Figure 8. Point counting XRF data for carbonate cements, Murlough Bay, Ulster Basin.

Late-stage authigenic mineral assemblages. SEM studies confirmed the presence of late-stage authigenic clay mineral assemblages: (i) pore-filling illite (Figure 2a), (ii) minor amounts of pore-filling kaolinite (Figure 2d), chlorite (Figure 2c) and (iii) minor amounts of pore-filling quartz crystals. These authigenic clay mineral assemblages occur in the sandy, silty and muddy facies. However, the abundance of authigenic clay minerals concentrated in the sandy facies. Grain dissolution, volcanic and hydrothermal activities possibly provided the necessary ions for the precipitation of late-stage authigenic minerals. The porosity and permeability enhanced the circulation of mineralized water in the pore space, to facilitate the precipitation of authigenic clay minerals. Tertiary uplift and erosion put the Permo-Triassic sandstones in the telodiagenesis 
regime. Leaching of feldspar grains may have occurred at this time. Late-stage clay minerals and quartz crystals probably precipitated by penetration of meteoric fluids enriched by silicon, aluminium and potassium ions into the basin. Some of these reactions continue at present time with ground water circulation.

$$
\underset{\text { K-feldspar }}{2 \mathrm{KAlSi}_{3} \mathrm{O}_{8}}+\underset{\text { Kaolinite }}{2 \mathrm{H}^{+}}+\mathrm{H}_{2} \mathrm{O}=\underset{\mathrm{Al}_{2} \mathrm{Si}_{2} \mathrm{O}_{5}(\mathrm{OH})_{4}}{\mathrm{H}^{2}}+4 \mathrm{SiO}_{2}+2 \mathrm{~K}^{+}
$$

Smectite $+\mathrm{K}^{+}+\mathrm{Al}^{3+}=$ Illite + quartz $+\mathrm{H}^{+}$

Smectite + K-feldspar $=$ Illite + chlorite + quartz

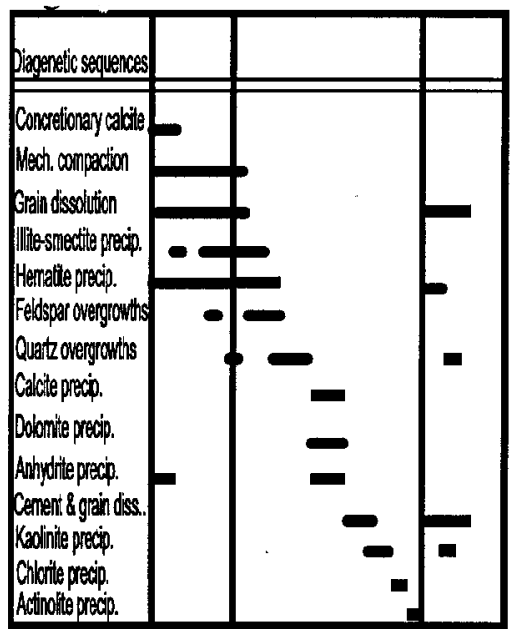

(a) Sandstone fades

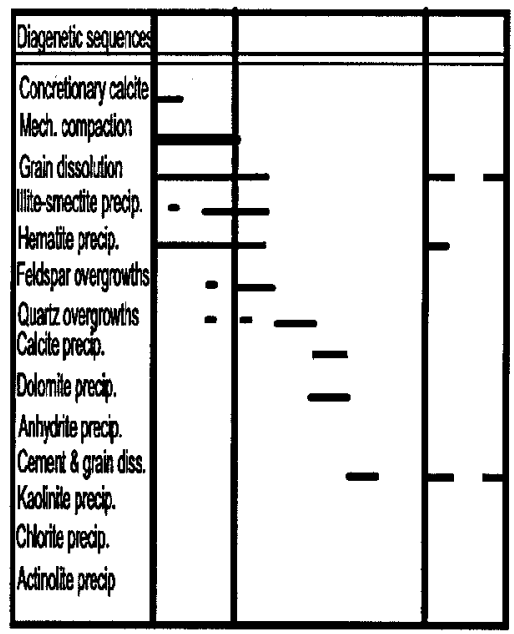

(c) Mudrock lacies

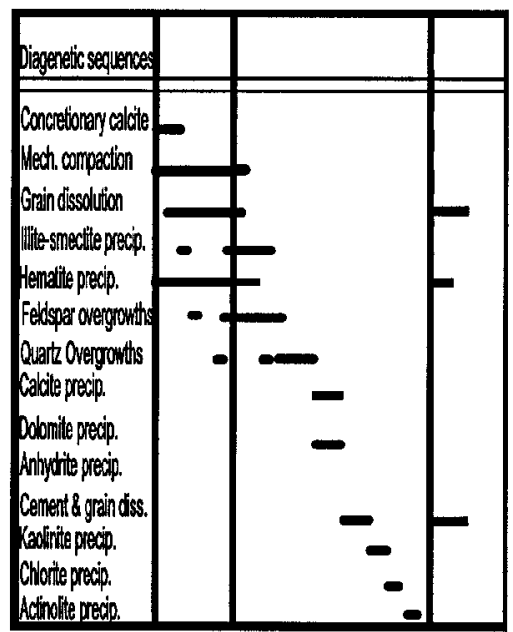

(b) Siltstone facies

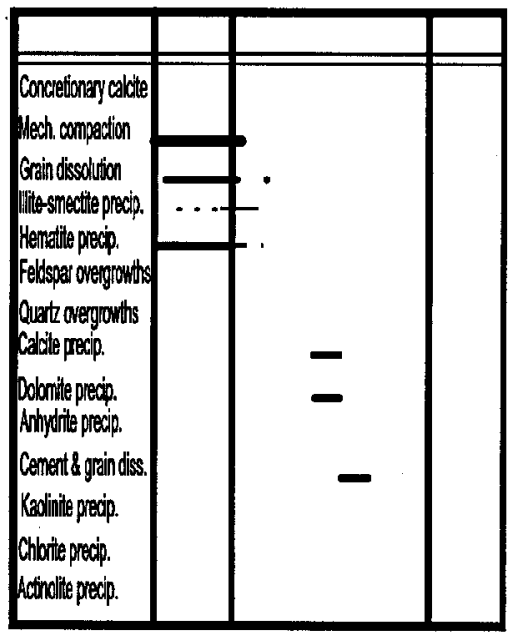

(d) Shaly facies

Figure 9. Digenetic minerals sequence of the Permo-Triassic sandstones and interbedded siltstone, mudstone and shale. 


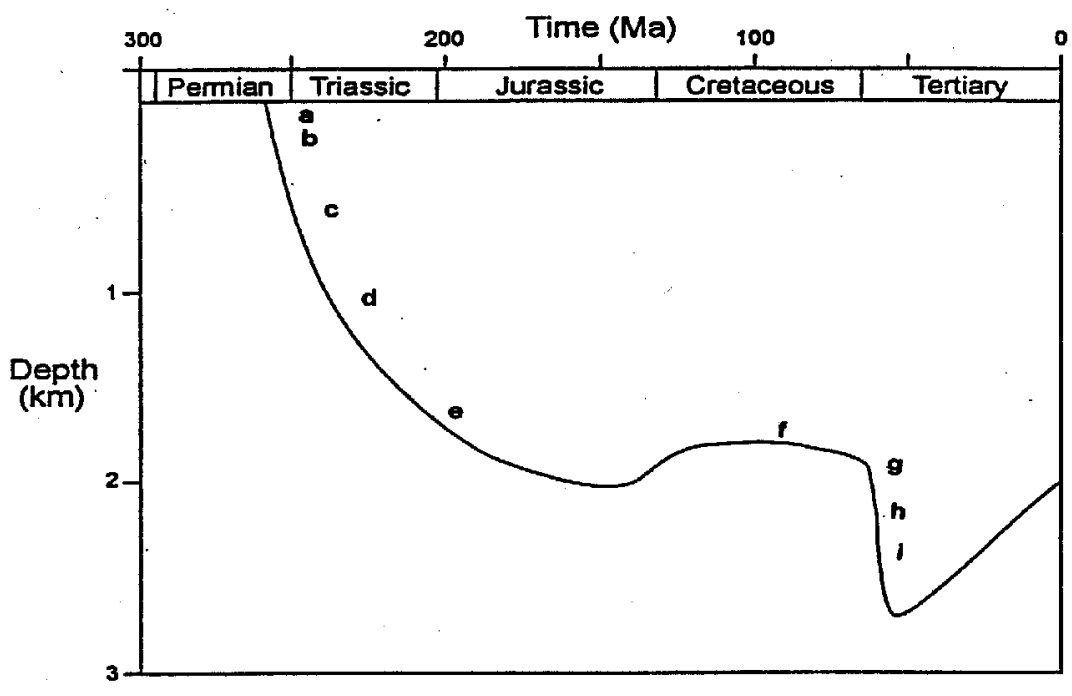

Figure 10. Diagenetic sequences of the Permo-Triassic sandstones. Plot framework (from Parnell, 1992a). a = calcrete, dolocrete and anhydrite, $b=$ mechanically infiltrated clay, $\mathrm{c}=$ illite-smectite, $\mathrm{d}=$ feldpspar and quartz overgrowths, $\mathrm{e}=$ calcite, dolomite and anhydrite precipitation, $\mathrm{f}=$ uplift and influx of acidic meteoric water and precipitation of kaolinite, $\mathrm{g}=$ reburial and volcanic activity and precipitation of illite and chlorite, $\mathrm{h}=$ actinolite precipitation, $\mathrm{i}=$ hydrocarbon emplacement.

Hematite $\left(\mathrm{Fe}_{2} \mathrm{O}_{3}\right)$ and ilmenite $\left(\mathrm{FeTiO}_{3}\right)$ cementation. Microprobe analysis of ilmenite in the muddy facies showed up to $66.24 \% \mathrm{Fe}_{2} \mathrm{O}_{3}, 31.49 \% \mathrm{TiO}_{2}$ and $1.42 \% \mathrm{SiO}_{2}$. Microprobe analysis of hematite cement in the muddy and silty facies exhibited up to $94.98 \% \mathrm{Fe}_{2} \mathrm{O}_{3}$ with impurities of $0.43 \% \mathrm{MgO}$ and $3.61 \% \mathrm{TiO}_{2}$. Microprobe analysis of hematite cement in the sandy facies revealed up to $96.19 \% \mathrm{Fe}_{2} \mathrm{O}_{3}$ with impurities of $2.11 \% \mathrm{TiO}_{2}$, whilst ilmenite cement contains up to $69.45 \% \mathrm{Fe}_{2} \mathrm{O}_{3}$ and $30.41 \% \mathrm{TiO}_{2}$.

XRF data for Murlough Bay (Figure 3) indicates that the concentration of $\mathrm{Fe}_{2} \mathrm{O}_{3}$ decreases from the base of the sandy breccia towards the sandy facies. The concentration of $\mathrm{Fe}_{2} \mathrm{O}_{3}$ in the upper part of the Mercia Mudstone Group is up to $6.58 \%$, decreasing towards the mudstonesandstone contact at $2.60 \%$. Intergranular dissolution of ferromagnesian minerals was possibly the most important source of ions for the precipitation of hematite and ilmenite within the sandy, silty and muddy facies. The distribution of authigenic minerals in the sandy, silty and muddy facies is given in Table 5 and Figure 9 and 10.

\section{DISCUSSION AND INTERPRETATION}

The Permo-Triassic sandstones are interbedded with organic-poor mudstones and siltstones throughout the entire section, and experienced a red bed diagenesis. In studying finegrained sediments, Fuchtbauer [5] distinguished 5 types of settings: (1) layers completely separated from the sand, (2) seams relatively well separated from sand, (3) uniformly distributed late stage authigenic clay, (4) uniform distribution of detrital and early diagenetic clay minerals, and (5) combinations of the above. The diagenetic processes in each case may be different. The studied sandstones, siltstones and mudstones are 
represented by case 5. At an early stage of diagenesis, large volumes of compactional mineralized pore water were introduced from the muddy and silty facies into the sandy facies. Mass transfer from the muddy facies to the sandy facies might have contributed to silica and carbonate authigenesis in the sandy facies. SEM studies and point counting (Figure 11 and 12) indicate an abundance of authigenic minerals (quartz, calcite and dolomite crystals), particularly in the sandy facies near the mudstone-sandstone and siltstone-sandstone contacts. The XRF data combined with the SEM results indicate the transfer of $\mathrm{SiO}_{2}, \mathrm{CaO}$ and $\mathrm{MgO}$ from the muddy facies to the sandy facies.

In late stage diagenesis, clay minerals reactions including dehydration and mineral transformation liberate ions into the diagenetic environment, which might contribute to the authigenesis of minerals in the muddy, silty and sandy facies. The solutes in the muddy and silty facies either precipitated within the facies or exported into the sandstone bodies. Some quartzcemented sandstones are separated vertically from potential silica source beds by a kilometer, requiring transport over long distance [6]. Acidic pore fluids with the capacity to dissolve and transport different ions are considered to be the most important means of transportation. Pore water generally migrated from argillaceous sediments into arenaceous sediments, whereas in the reverse direction the migration is more restricted. Depending upon the permeability distribution, pore water can migrate upward, downward and laterally (see Figure 13). Pore water may also migrate due to a pressure difference from the basinal (depocenter) towards the marginal areas of a basin if supported by permeability distribution.

The close similarity of the paragenetic sequences of the authigenic minerals in the sandy facies and the interbedded siltstone and mudstone facies indicates the same sequences of diagenetic events. The reactions that took place in the sandy facies also took place in the interbedded muddy and silty facies. The muddy and silty facies is frequently interbedded in the Permo-Triassic sandstones throughout the entire section. In such stratigraphic settings, the ions for the authigenesis of quartz, feldspar and carbonate cements might have come from the interbedded mudstones and siltstones.

The variation in $\mathrm{Al}_{2} \mathrm{O}_{3}$ content in the sandy, silty and muddy facies may be due to the variation in the ratio of quartz to the sum of clays, micas and feldspar. The variation in the content of $\mathrm{Al}_{2} \mathrm{O}_{3}$ is a function of depositional environment. The flood-plain sediments contain much low-energy suspension load materials rather than high-energy coarse-grained quartz and feldspars. XRF data for the Murlough Bay section shows a mass transfer of $\mathrm{K}_{2} \mathrm{O}$ and $\mathrm{Al}_{2} \mathrm{O}_{3}$ from the muddy facies to the sandy facies. However, the Cultra data plot exhibits less evidence of mass transfer from the muddy facies to the sandy facies. Export of most of the products released by dissolution of detrital feldspar is strongly suggested [7]. The most important ion sources for the precipitation of authigenic feldspar and albite could be intergranular dissolution of unstable grains (feldspar and mafic minerals) within the system, with minor amounts of contribution from the overlying and intebedded mudstones and siltstones.

$$
\begin{aligned}
& \mathrm{NaAlSi}_{3} \mathrm{O}_{8}+8 \mathrm{H}_{2} \mathrm{O}=\mathrm{Na}^{+}+3 \mathrm{Si}(\mathrm{OH})_{4}+\mathrm{Al}^{3+}+4 \mathrm{OH}^{-} \\
& 2 \mathrm{NaAlSi}_{3} \mathrm{O}_{8}+2 \mathrm{CO}_{2}+11 \mathrm{H}_{2} \mathrm{O}=\mathrm{Al}_{2} \mathrm{Si}_{3} \mathrm{O}_{5}(\mathrm{OH})_{4}+2 \mathrm{Na}^{+}+2 \mathrm{HCO}_{3}{ }^{-}+4 \mathrm{H}_{4} \mathrm{SiO}_{4}
\end{aligned}
$$

Silica is introduced by water expelled from shales, mudstones and siltstones during compaction $[5,8]$. The silicon ions might have been precipitated within the silty and muddy facies, near the siltstone-sandstone contact and mudstone-sandstone contact or transported from a remote distance into the sandstone body depending upon the permeability distribution and super saturation. Mudstones may have exported $10-20 \%$ of their detrital quartz to adjacent sandstones [9]. The origin and mechanism of silica transport, timing of cementation, and controls on cement distribution remain matter of debate $[6,10,11]$. The following could be 
possible sources for the silica budget for the studied sandy facies during early stage quartz cementation: (i) dissolution of unstable grains of feldspar, (ii) compactional water from the interbedded and overlying mudstones, siltstones and shales, and (iii) dissolution of silt-size detrital quartz and other silicates from the interbedded siltstones and mudstones.

During an early stage diagenesis the fine-grained sediments (shales, siltstones and mudstones) are more susceptible to dissolution than coarse-grained sandstones. Pressure solution is a possible mechanism for the generation of silica cement from the interbedded mudstones [12, 13]. Pressure dissolution of silica is minor in the upper $1500 \mathrm{~m}$ of the sediments, but increases in a roughly linear manner with depth [14]. Quartz-rich mudstones and siltstones that have undergone pressure dissolution may be possible sources for the generation of silica cement in the sandstone-rich section of the basin. Extensive quartz crystals near the mudstone-sandstone interface indicate mass transfer by diffusion [13]. Other sources at temperatures above $75{ }^{\circ} \mathrm{C}$ included dissolution of quartz at stylolites [e.g. 15, 9, 16, 17]; dissolution of grain contacts [e.g. $18,16,17]$, and clay mineral reactions in shale $[$ e.g. 19, 20]. The intercalation of mudstones and siltstones throughout the entire section of the Permo-Triassic sandstones facilitated silica transformation through diffusion or infiltration. Diffusion is considered to be the most important means of short distance migration of ions using the concentration gradient [e.g. 21, 9, 12]. Calculations show that diffusion alone accounts for most of mass transfer, and silica transport by diffusion is possible over 3-5 meters [e.g. 22, 13].

The distribution of authigenic quartz differs from formation to formation, from bed to bed, also within the same bed. This might be due to variations in permeability distribution and the super saturation of the pore water with silica ions. More authigenic quartz is observed in the sandy facies than in the studied silty and muddy facies, due to loss of porosity in the silty and muddy facies. It is also notable that the main phase of quartz cementation pre-dated pressure solution, stylolitization and clay mineral transformation. Precipitation of quartz overgrowths took place at an early stage of diagenesis. This might have been related to the dissolution of unstable grains due to the percolation of meteoric water. Pressure solution, stylolitization and clay mineral transformation were possible sources for the late stage authigenesis of quartz crystals. The main factors that control the amount of quartz cement in a sandstone are framework composition, residence time in the silica mobility window, fluid composition, fluid path and flow volume, which are variables dependent upon tectonics, type of sedimentary basin, composition and relief of the source area [21].

The carbonate-rich sandy breccia could be the possible source for carbonate cement in the sandy facies. SEM studies of the interbedded sandstone in the Mercia Mudstone Group indicate a high concentration of dolomite and calcite crystals. Point counting shows that the interbedded carbonate-cemented sandstones in the Mercia Mudstone Group contain up to $48 \%$ calcite and dolomite cements, indicating that most of the calcium and magnesium ions for the precipitation of carbonate cements came from the interbedded mudstones, siltstones and shales. The high concentrations of $\mathrm{CaO}$ and $\mathrm{MgO}$ in the sandstone beds that are interbedded in the Mercia Mudstone Group also suggest mass transfer from the muddy facies to the sandy facies. This indicates that a significant part of the carbonate budget may have come from both the overlying highly carbonate-cemented Mercia Mudstone Group and underlying carbonate-rich sandy breccia. 

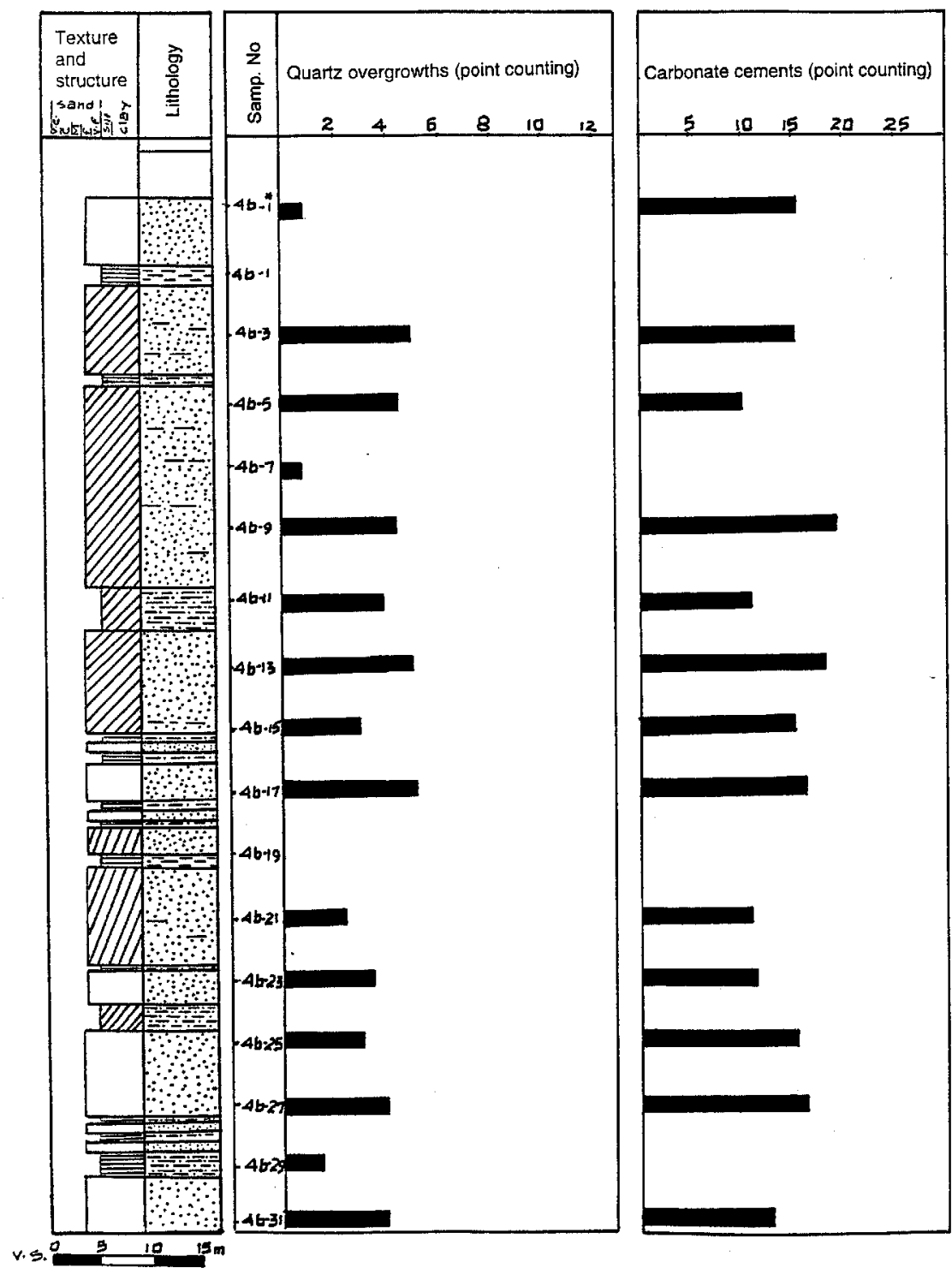

Figure 11. Content of quartz overgrowths and carbonate cements in percent, borehole 4B, Lagan Valley, Ulster Basin.

The possible sources for carbonate in the sandy facies include: (i) dissolution of ferromagnesian minerals, (ii) percolation of mineralized water from the interbedded mudstones and siltstones, (iii) percolation of mineralized pore water from the overlying Mercia Mudstone Group, and (iv) influx of calcium and magnesium-rich meteoric water into the sand bodies. During diagenesis, mineralized pore water migrated from the muddy and silty facies to the sandy facies. In subsiding rift basins, multiple phases of carbonate cementation and decarbonitization processes are common. The presence of calcite, ferroan calcite, dolomite, ferroan dolomite and ankerite indicate variations in the pore water chemistry due to different mineralogical reaction in 
specific diagenetic environments [23, 11]. In an arid environment, early carbonate cements contain iron and manganese oxides [21]. Calcite, ankerite and anhydrite cementation can represent either early stage or late stage precipitation [12]. Ferroan calcite and ferroan dolomite can precipitate in either early stage or late stage diagenesis depending upon the super saturation of the pore water with respect to iron ions. Ankerite precipitation can take place within a range of temperatures ranging from $80-125^{\circ} \mathrm{C}$ [24]. Sandstone Siltstone Mudrock Abund-ance Shale

Table 5. Detriatal and authigenic mineral abundance in Permo-Triassic sandstones and interbedded siltstone and mudstone.

\begin{tabular}{|l|c|}
\hline Sandstone & $\begin{array}{c}\text { Abund- } \\
\text { ance }\end{array}$ \\
\hline Quartz & $\mathrm{xxxx}$ \\
Feldspar & $\mathrm{xxxx}$ \\
Rock & \\
fragments & $\mathrm{x}$ \\
Detrital clay & $\mathrm{x}$ \\
Micas & $\mathrm{x}$ \\
$\begin{array}{l}\text { Heavy } \\
\text { minerals }\end{array}$ & $\mathrm{x}$ \\
\hline
\end{tabular}

\begin{tabular}{|c|c|}
\hline Siltstone & $\begin{array}{c}\text { Abund- } \\
\text { ance }\end{array}$ \\
\hline Quartz & $\mathrm{xxxx}$ \\
\hline Feldspar & $\mathrm{xxx}$ \\
\hline $\begin{array}{l}\text { Rock } \\
\text { fragments }\end{array}$ & \\
\hline Detrital clay & $\mathrm{xxx}$ \\
\hline $\begin{array}{l}\text { Micas } \\
\text { Heavy } \\
\text { minerals }\end{array}$ & $\mathrm{xX}$ \\
\hline
\end{tabular}

\begin{tabular}{|l|c|}
\hline Mudrock & $\begin{array}{c}\text { Abund- } \\
\text { ance }\end{array}$ \\
\hline Quartz & $\mathrm{xx}$ \\
Feldspar & $\mathrm{xxx}$ \\
Rock fragments & $\mathrm{x}$ \\
Detrital clay & $\mathrm{xxxx}$ \\
Micas & $\mathrm{xx}$ \\
Heavy minerals & $\mathrm{x}$ \\
\hline
\end{tabular}

\begin{tabular}{|l|c|}
\hline Shale & $\begin{array}{c}\text { Abund- } \\
\text { ance }\end{array}$ \\
\hline Quartz & $\mathrm{x}$ \\
Feldspar & $\mathrm{xxx}$ \\
Rock fragments & $\mathrm{xx}$ \\
Detrital clay & $\mathrm{xxx}$ \\
Micas & $\mathrm{xx}$ \\
Heavy minerals & $\mathrm{x}$ \\
\hline
\end{tabular}

\begin{tabular}{|c|c|}
\hline \multicolumn{2}{|l|}{ Sandstone } \\
\hline $\begin{array}{l}\text { Authigenic } \\
\text { minerals }\end{array}$ & $\begin{array}{l}\text { Abund- } \\
\text { ance }\end{array}$ \\
\hline Illite-smectite & $\mathrm{xx}$ \\
\hline \begin{tabular}{|l|} 
Feldspar \\
overgrowths
\end{tabular} & $\operatorname{xxxx}$ \\
\hline $\begin{array}{l}\text { Quartz } \\
\text { overgrowths }\end{array}$ & $\mathrm{xxx}$ \\
\hline Calcite cement & $\operatorname{xxxx}$ \\
\hline $\begin{array}{l}\text { Dolomite } \\
\text { cement }\end{array}$ & $\mathrm{xxxx}$ \\
\hline $\begin{array}{l}\text { Kaolonite } \\
\text { precipitation }\end{array}$ & $\mathrm{xx}$ \\
\hline $\begin{array}{l}\text { Euhedral } \\
\text { quartz }\end{array}$ & $\mathrm{x}$ \\
\hline $\begin{array}{l}\text { Euhedral } \\
\text { feldspar }\end{array}$ & $\mathrm{X}$ \\
\hline $\begin{array}{l}\text { Hamatite } \\
\text { precipitation }\end{array}$ & $\mathrm{xX}$ \\
\hline $\begin{array}{l}\text { Illite } \\
\text { precipitation }\end{array}$ & $\mathrm{XX}$ \\
\hline
\end{tabular}

\begin{tabular}{|c|c|}
\hline \multicolumn{2}{|l|}{ Sandstone } \\
\hline $\begin{array}{l}\text { Authigenic } \\
\text { minerals }\end{array}$ & $\begin{array}{l}\text { Abund- } \\
\text { ance }\end{array}$ \\
\hline Illite-smectite & $\mathrm{xx}$ \\
\hline $\begin{array}{l}\text { Feldspar } \\
\text { overgrowths }\end{array}$ & $\mathrm{XxX}$ \\
\hline $\begin{array}{l}\text { Quartz } \\
\text { overgrowths }\end{array}$ & $\mathrm{xx}$ \\
\hline Calcite cement & $\mathrm{xxx}$ \\
\hline $\begin{array}{l}\text { Dolomite } \\
\text { cement }\end{array}$ & $\mathrm{xx}$ \\
\hline $\begin{array}{l}\text { Kaolonite } \\
\text { precipitation }\end{array}$ & $\mathrm{X}$ \\
\hline $\begin{array}{l}\text { Euhedral } \\
\text { quartz }\end{array}$ & $\mathrm{X}$ \\
\hline $\begin{array}{l}\text { Euhedral } \\
\text { feldspar }\end{array}$ & $\mathrm{X}$ \\
\hline $\begin{array}{l}\text { Hamatite } \\
\text { precipitation }\end{array}$ & $\mathrm{xx}$ \\
\hline $\begin{array}{l}\text { Illite } \\
\text { precipitation }\end{array}$ & $\mathrm{x}$ \\
\hline
\end{tabular}

\begin{tabular}{|c|c|}
\hline \multicolumn{2}{|l|}{ Mudrock } \\
\hline $\begin{array}{l}\text { Authigenic } \\
\text { minerals }\end{array}$ & $\begin{array}{c}\text { Abund- } \\
\text { ance }\end{array}$ \\
\hline Illite-smectite & $\mathrm{x}$ \\
\hline $\begin{array}{l}\text { Feldspar } \\
\text { overgrowths }\end{array}$ & $\mathrm{xx}$ \\
\hline $\begin{array}{l}\text { Quartz } \\
\text { overgrowths }\end{array}$ & \\
\hline Calcite cement & $\mathrm{xx}$ \\
\hline Dolomite cement & $\mathrm{xx}$ \\
\hline $\begin{array}{l}\text { Kaolonite } \\
\text { precipitation. }\end{array}$ & $\mathrm{x}$ \\
\hline Euhedral quartz & $\mathrm{x}$ \\
\hline Euhedral feldspar & $\mathrm{x}$ \\
\hline \begin{tabular}{|l|} 
Hamatite \\
precipitation \\
Illite \\
precipitation \\
\end{tabular} & $\mathrm{x}$ \\
\hline
\end{tabular}

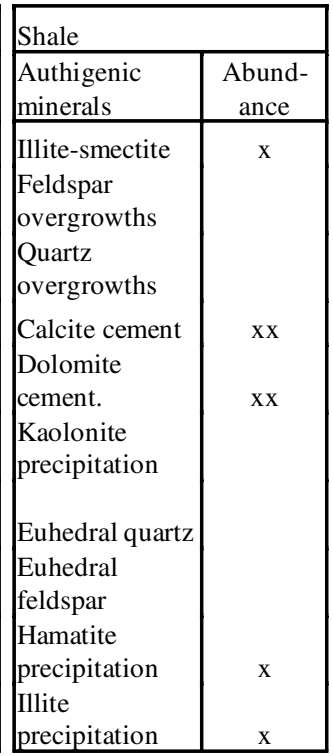

Key: $\mathrm{xxxx}=$ major, $\mathrm{xxx}=$ moderate, $\mathrm{xx}=$ minor, $\mathrm{x}=$ very minor .

Based on the diagenetic sequences of authigenic minerals in the muddy, silty and sandy facies, it is possible to suggest a model of evolving pore water chemistry to explain the mineral sequences from early to late-stage diagenesis: (1) facies-related intermittent enrichment of calcium carbonate lead to the precipitation of concretionary calcite (calcrete); (2) influx of gravity-driven acidic meteoric water facilitated dissolution of unstable framework grains. The reaction rate between rock-forming minerals and pore water is low at low temperature and leaching and mass transfer can occur for a longer distance since saturation is not reached rapidly $[15,25]$. The dissolution of unstable minerals released ions of silicon, aluminium, potassium, 
sodium, calcium, magnesium and iron into the pore water for the precipitation of various types of authigenic minerals.

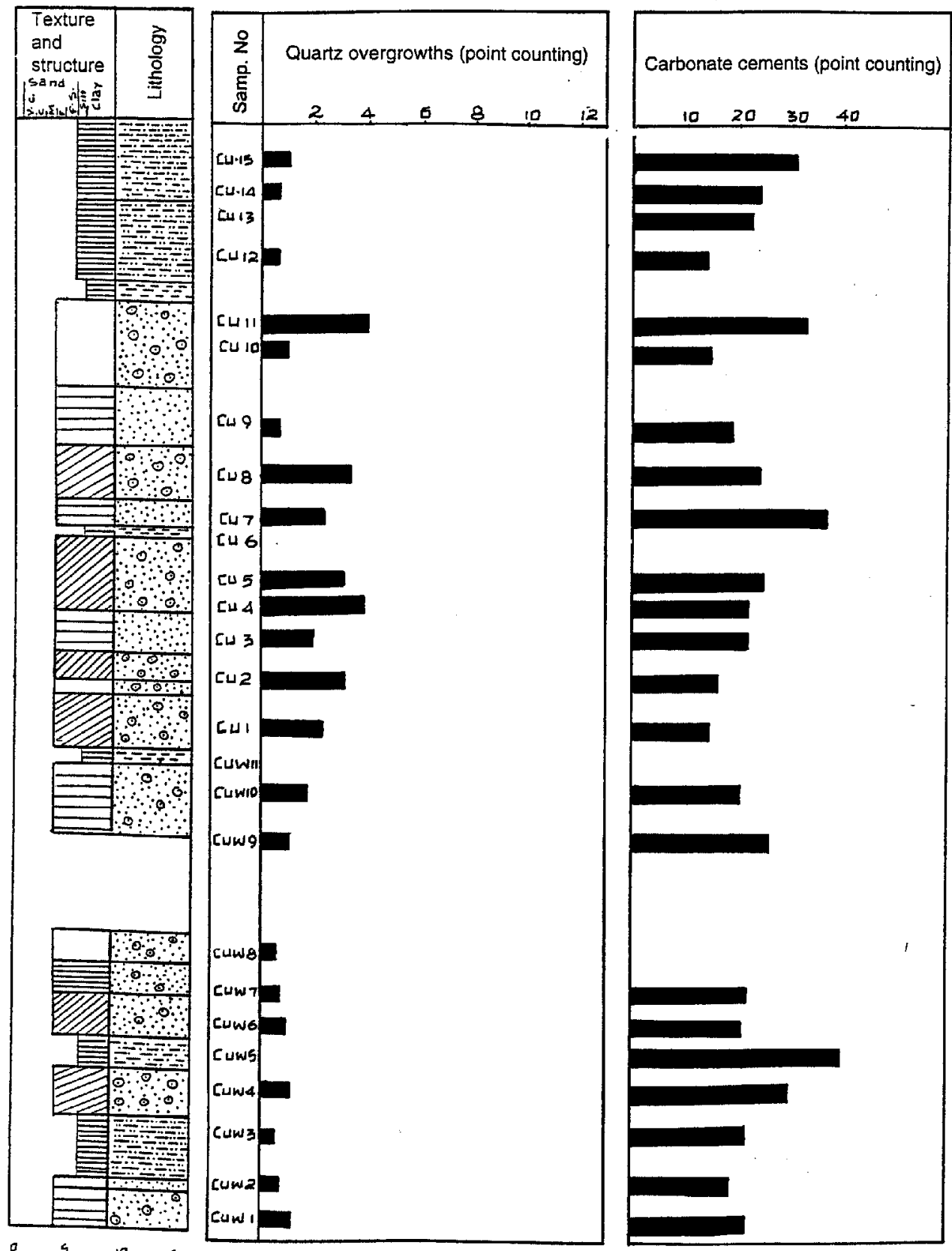

Figure 12. Content of quartz overgrowths and carbonate cements in percent, Cultra, Ulster Basin.

$$
\mathrm{Mg}_{2} \mathrm{SiO}_{4}+4 \mathrm{H}_{2} \mathrm{O}=2 \mathrm{Mg}^{2+}+4 \mathrm{OH}+\mathrm{Si}(\mathrm{OH})_{4}
$$




$$
\begin{aligned}
& \mathrm{KAlSi}_{3} \mathrm{O}_{8}+6 \mathrm{H}_{2} \mathrm{O}+2 \mathrm{H}+2 \mathrm{HCO}_{3}=3 \mathrm{Si}(\mathrm{OH})_{4}+\mathrm{K}^{+}+\mathrm{Al}(\mathrm{OH})_{2}+2 \mathrm{HCO}_{3}^{-} \\
& \mathrm{CaAl}_{2} \mathrm{SiO}_{8}+2 \mathrm{CO}_{2}+3 \mathrm{H}_{2} \mathrm{O}=\mathrm{Al}_{2} \mathrm{Si}_{2} \mathrm{O}_{5}(\mathrm{OH})_{4}+\mathrm{Ca}^{2+}+2 \mathrm{HCO}_{3}^{-}
\end{aligned}
$$

The reaction between the rock-forming minerals and pore water increased the $\mathrm{pH}$ value and the precipitation of grain-coating illite-smectite/hematite pore-filling illite-smectite, feldspar overgrowths and quartz overgrowths took place. During late-stage diagenesis carbon dioxide was released from mature carboniferous source rocks into the diagenetic environment. The burial depth of the Permo-Triassic sandstones was greater than $2.5 \mathrm{~km}$ after the Cimmerian Uplift [26]. The depth range between 1.5 to $3 \mathrm{~km}$ facilitated the transformation of smectite to illite [20], and liberated large volumes of carbon dioxide, and provided dehydration water and ions of silicon, iron, sodium and calcium into the diagenetic environment. Organically and inorganically released carbon dioxide created an acidic environment to leach out carbonate cements and unstable grains to generate secondary porosity. The reaction between acidic pore water and carbonate and unstable grains increased the $\mathrm{pH}$ value, and the late stage kaolinite and quartz authigenesis took place. Activity diagram for the potassium oxide-silicon oxidealuminium oxide-water system, and precipitation of authigenic minerals is given in Figure 14.

\section{Means of pore water and mass transfer}

(a) Mechanical compaction. Mechanically compacted mudstones and siltstones expelled large volumes of mineralized pore water, which migrated into the sandstone-rich section of the basin. The pore fluid expelled from the muddy facies has a significant role in the trend of sandstone diagenesis. Some workers $[$ e.g. 12, 27, 11] have stressed that the amount of pore fluids released from muddy and clayey sediments determine how, when, and to what degree sandstone diagenesis occurs. Mineralized pore waters are liberated during compaction from both the overlying and underlying mudstones $[$ e.g. 28, 13, 29, 11]. The initial mineralogical composition dictates the type of ions to be released into the pore waters. Assuming $80 \%$ water content in mud [9], the amount of pore water discharged from the overlying Mercia Mudstone Group can be calculated:

\begin{tabular}{|lccc|}
\hline Borehole & Present thickness $(\mathrm{m})$ & Original thickness $(\mathrm{m})$ & Amount of water $(\mathrm{m})$ \\
\hline Magilligan & 450 & 2250 & 1800 \\
Port More & 650 & 3250 & 2600 \\
Larne & 700 & 3500 & 2800 \\
New Mill & 450 & 2250 & 1800 \\
Ballymacilroy & 500 & 2500 & 2000 \\
Mulaghglass & 200 & 1000 & 800 \\
Killary Glebe & 50 & 250 & 200 \\
Langford Lodge & 200 & 1000 & 800 \\
Average & 400 & 2000 & 1600 \\
\hline
\end{tabular}



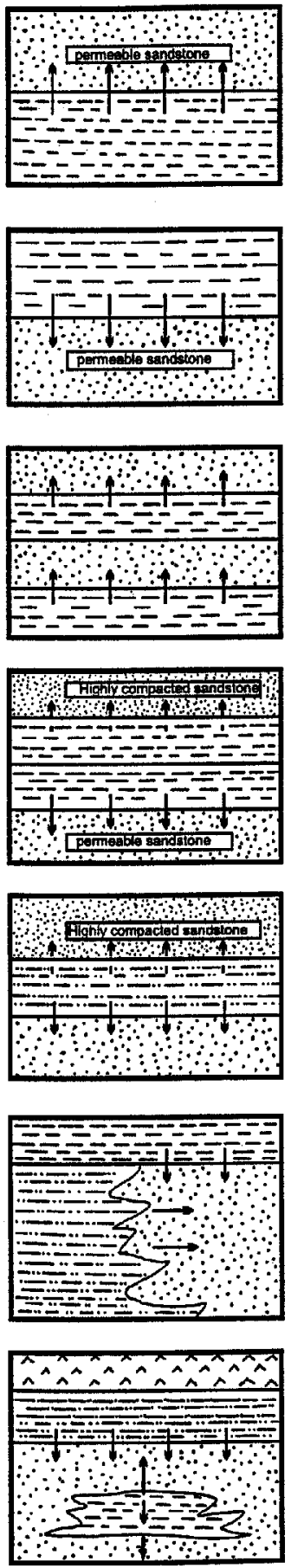

Case 1: Upward migration

Where the shaly facies is overlain by sandy facies the pore water migrates upward from the shaly facies into the sandy facies.
Case 2: Downward migration

Where the sandstone facies is overiain by the shaly facies the pore water migrates from the shaly facies downward into the sandy facies. The pore water will not migrate upward.

Case 3: Upward migration

The pore water migrates upward from individual shale beds into the adjacent sandstone.

Case 4: upward and downward migration The pore water mirates either downward or upward. The compactional pore water from the shaly facies migrates upward whereas the pore water from the muddy facies migrates downward into the sandy facies.

Case 5: Downward and upward migration The compactional pore water migrates into the porous sandstone. Restricted water migrates into highly compacted sandstone.

Case 6: Lateral (stratiform) migration The pore water migrates from the muddy facies laterally into the sandstone beds.

Case 7: Lateral and downward migration The pore water migrates from muddy and shaly facies laterally and downward into sandy facies.

$\square$ Unrestricted pore water migration $-\rightarrow$ Restricted pore water migration

Figure 13. Pore water migration model based on permeability distribution. 
The amount of mineralized pore water discharged from the Mercia Mudstone Group is equal to the surface area of the basin multiplied by the average thickness of the water, which is equal to $60,000 \mathrm{~m} \times 90,000 \mathrm{~m} \times 1600 \mathrm{~m}=8,640,000,000,000 \mathrm{~m}^{3}$. Undoubtedly a significant part of this mineralized water migrated into the sandstone-rich section of the basin, i.e. Permo-Triassic sandstones. In a similar way the amount of pore water discharged from the interbedded mudstones in the Permo-Triassic sandstones can be calculated from the present thickness of each bed. Mechanically compacted pore water migrated upward, downward or laterally depending upon the permeability distribution. The freer movement of formation water along bedding planes helped to expel mineralized water from the silty, muddy and shaly facies into the sand-rich section of the basin. Pore water also migrated due to pressure differential from the basinal areas (depocenter) to the marginal areas of the basin, if supported by the regional permeability distribution. The possible pore water and mass transfer model in the studied sandstones, siltstones and mudstones is given in Figure 13.

(b) Meteoric water. Meteoric water plays a major role in the transport of dissolved ions from the source terrains, and also causes dissolution of unstable grains in the diagenetic environment. In rift basins, gravity-driven meteoric water flow can penetrate at least several kilometers into the sedimentary basin. Gravity-driven acidic meteoric water in the diagenetic environment plays a significant role in leaching and circulating ions $\left(\mathrm{Si}^{4+}, \mathrm{Al}^{3+}, \mathrm{K}^{+}, \mathrm{Ca}^{2+}, \mathrm{Mg}^{2+}, \mathrm{Fe}^{2+}, \mathrm{Fe}^{3+}\right)$ downwards in the basin, for the precipitation of different authigenic minerals. The intergranular primary porosity in arkosic arenites and quartz arenites dominates the Permo-Triassic sandstones that reach to a depth of nearly $3 \mathrm{~km}$, and allow the downward circulation of meteoric water and ions. In studying the diagenesis of sandstones, attempts are now made to reconstruct the lagerscale, basin-wide patterns of pore water movements through the sediments. Recharges from continental upland areas allow meteoric water to penetrate to great depths in sedimentary sequences $[$ e.g. 9, 30, 11]. A number of studies suggest that the dissolution of unstable grains by meteoric water as one of the sources for silica cement $[$ e.g. 6, 12, 20]. Quartoze sandstones in intracratonic basins will retain considerable permeability after burial permitting long-term cementation by quartz $[6,31]$.

(c) Diffusion-type transport. Diffusion of quartz from the adjacent shales into sandstone beds was proposed by [5]. Salinity gradient differences will set up diffusion, may cause a pressure difference and concentration gradient will cause a diffusion-type transport [9]. Diffusion possibly plays a significant role in quartz and carbonate crystals precipitation in the sandy facies near the mudstone-sandstone and siltstone-sandstone contacts.

(d) Convection. Abnormal temperatures due to intrusive and extrusive volcanic activity in the Ulster Basin caused convection of the formation waters. The Permian Sandstone in the Ulster Basin was interrupted by $1500 \mathrm{~m}$ thick basaltic lava flows [33], which might have provided ions for the precipitation of chlorite in the pore spaces. Studies of sandstones, siltstones and mudstones near the Tertiary dykes indicate that the presence of chlorite might have been favoured by magnesium and iron ions released from volcanic activity and hydrothermal effects [37]. Samples from the Scrabo Hill Quarry also indicate the presence of actinolite cementation. Magnesium and iron ions for the authigenesis of actinolite might have been favoured from volcanic and hydrothermal effects from the doleritic dykes and sills [11].

(e) Dehydration water. Expulsion of pore water is a continuous process until hydrated clay minerals are transformed to illite and chlorite. Dehydration and clay mineral transformations provide mineralized water during the late-stage diagenesis. 


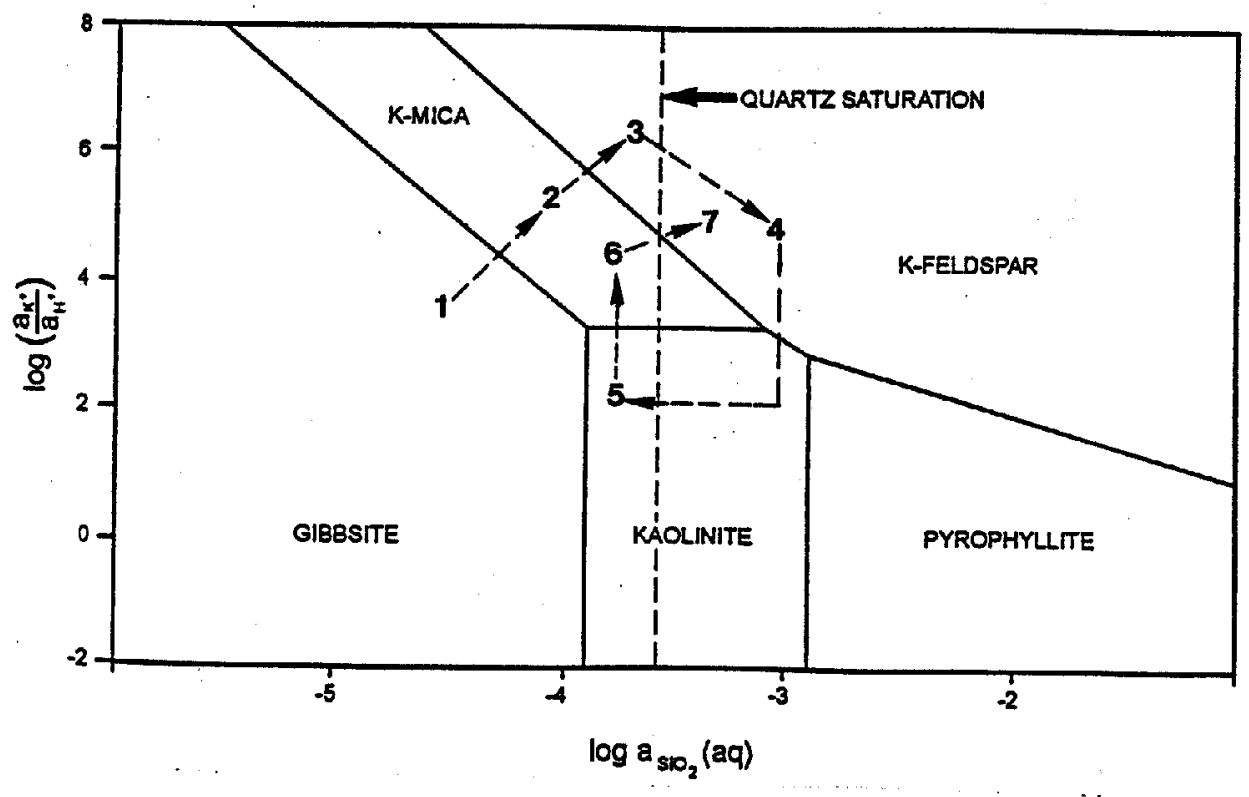

Figure 14. Activity diagram for potassium oxide-silicon oxide-aluminium oxide-water system. (1) calcrete, dolocrete and anhydrite precipitation under brackish conditions, (2) increased potassium, aluminium and silicon ions to precipitate illite, (3) increased dissolved ions of potassium, aluminium and silicon ions and co-precipitation of illite and K-feldspar, (4) silicon ions supersaturation and precipitation of quartz overgrowths, (5) increased activity of silicon, and aluminium and precipitation of kaolinte, (6) increased activity of potassium, aluminium and silicon to precipitate illite, and (7) increased activity of silicon and precipitation of late stage euhedral quarz crystals. Phase boundaries for $50{ }^{\circ} \mathrm{C}$ and 150 bars.

\section{CONCLUSIONS}

The following conclusions are drawn from the comparison of authigenic minerals, diagenetic sequences, and mass transfer of sandstones, siltstones and mudstones in the Ulster Basin.

(1) Reconstruction of the paragenetic sequences in sandstones and the interbedded mudstones and siltstones of the Ulster Basin revealed the same authigenic mineral association and the same red bed diagenetic trend.

(2) The diagenetic processes that took place in the sandy facies also took place in the muddy and silty facies. Grain-coating clay/hematite, quartz overgrowths, feldspar overgrowths and carbonate cementation are also occurred in the fine-grained sediments (siltstones and mudstones). There is a greater abundance of authigenic minerals in the sandy facies than in the silty and muddy facies, which might be related to the distribution of permeability in the sandy facies, which acted as a conduit for formation water circulation.

(3) SEM and XRF studies indicate that some part of the silica and carbonate budget for the sandy facies might have come from the interbedded mudstones, siltstones and shaly facies. The presence of authigenic quartz and carbonate crystals in some of the studied sandstones near the mudstone-sandstone and siltstone-sandstone contact indicates pore water and mass transfer from the fine-grained sediments (siltstones, mudstones and shales). 
(4) The distribution of quartz and feldspar overgrowths and crystals varies from formation to formation, beds to beds, within the same bed, and also within the same thin section. This might be related to the distribution of permeability and the super saturation of the pore water with respect to silicon, potassium and aluminium ions. Authigenic quartz and feldspar occur in decreasing abundance from sandstone to siltstone to mudstones.

(5) Excepting minor amounts of authigenic illite-smectite and illite the shaly facies is dominated by detrital illite, smectite, dolomite, quartz and feldspar. Extensive carbonate cementation is a feature common to channel sandstones and over-bank fines (mudstones, siltstones and shales).

(6) Mechanical compaction of fine-grained sediments, influx of gravity-driven acidic meteoric pore water, dehydration water, diffusion and convection are the most important means of mass transfer. Pore water and ions circulation depends upon permeability distribution and pressure differentials.

(7) Gravity-driven acidic meteoric water in the diagenetic environment plays a significant role in leaching and circulating ions downwards in the basin, for the precipitation of different authigenic minerals. In rift basins, gravity-driven meteoric water flow can penetrate at least several kilometers into the sedimentary basin.

\section{ACKNOWLEDGEMENTS}

This study is a part of the Ph.D. research project supervised by Dr. J. Parnell and his help and comments are gratefully acknowledged. Thanks are also extended to Dr. E. GierlowskiKordesch, Dr. A. Ruffell, Mr. A. Assefa, and T. Ketsela. Most of the work was carried out at the School of Geosciences, Geochemical Laboratory and Electron Microscopy Unit, the Queen's University of Belfast. This research work was financially supported by Ministry of Mines and Energy, Ethiopia and the School of Geosciences, the Queen's University of Belfast, U.K.

\section{REFERENCES}

1. Welton, J.E. SEM Petrology Atlas (Method in Exploration Series), American Association of Petroleum Geologist: Tulsa, Oklahoma, USA; 1984; p 237.

2. Pye, K.; Krinsley, O.H. J. Sed. Petrol. 1984, 54, 877.

3. School, P.A. A Colour Illustrated to Constituents, Texture, Cement and Porosities of Sandstones and Associated Rocks. AAPG Mem. 28, American Association of Petroleum Geologists: Tulsa, Oklahoma, USA; 1979.

4. Houseknecht, D. J. Sed. Petrol. 1984, 54, 348.

5. Fuchtbauer, H. Proc. 7th World Pet. Congr. Mexico; 1967, 2, 353.

6. McBride, E.F. Ear. Sci. Rev. 1989, 26, 69.

7. Milliken, K.L. J. Sed. Petrol. 1989, 59, 361.

8. Moncare, G.K.; Lahann, R.W.; Siebert, R.M. Clastic Diagenesis, Vol. 37, McDonald, D.A.; Surdam, R.C. (Eds.); AAPG Mem. American Association of Petroleum Geologists: Tulsa, Oklahoma, USA; 1984; pp 151-161.

9. Bjorlykke, K. Sed. Geol. 1993, 86, 137.

10. Morad, S.; Bergan, M.; Knarud, D.R.; Nystuen, J.P. J. Sed. Petrol. 1990, 60, 411.

11. Ahmed, W. Ph.D. Thesis, The Queen's University of Belfast, U.K., 1997.

12. Fuchtbauer, H. Sediment Diagenesis, Parker, A.; Sellwood, B.W. (Eds.); D. Reidel Publishing Company: Dordrecht, Holland; 1983; pp 269-288.

13. Mullis, A.M. Sedimen. 1992, 39, 99. 
14. Chilingarian, G.V. Sedimentary Diagenesis, Parker, A.; Sellwood B.W. (Eds.); D. Reidel Publishing Company: Dordrecht, Holland; 1983; pp 57-167.

15. Bjorlykke, K.; Ramm, M.; Salgal, G.C. Geolo. Rdsch. 1989, 78, 243.

16. Sibley, D.F.; Blatt, H. J. Sed. Petrol. 1976, 46, 881.

17. Walderhaug, O. J. Sed. Res. 1994, 64, 311.

18. Houseknecht, D. J. Sed. Petrol. 1988, 58, 228.

19. Boles, J.R.; Franks, S.G. J. Sed. Petrol. 1979, 49, 55.

20. Hower, J.; Eslinger, E.V.; Hower, M.E.; Perry, E.A. Geol. Soc. Am. Bull. 1976, 87, 725.

21. Bjorlykke, K. Sediment Diagenesis, Parker, A.; Sellwood, B.W. (Eds.); D. Reidel Publishing Co.: Dordrecht, Holland; 1983; pp 169-213.

22. Egeberg, S.N.; Aagaard, P. Appl. Geochem. 1989, 4, 131.

23. Curtis, C.D. J. Geol. Soc. Lond. 1978, 135, 107.

24. Dutton S.P.; Diggs, T.N. J. Sed. Petrol. 1991, 60, 192.

25. Giles, M.R. Mar. Petro. Geol. 1987, 4, 188.

26. Parnell, J. J. Petrol Geol. 1992, 15, 51.

27. Power, M.C. AAPG Bull. 1967, 51, 1240.

28. Baker, J.C. Sedimen. 1991, 38, 819.

29. Purvis, K. Sed. Geol. 1992, 77, 155.

30. Tucker, M.E. Sedimentary Petrology and Introduction to the Origin of Sedimentary Rocks, 2nd ed., Blackwell Limited: London; 1996; p 260.

31. Blatt, H. Aspects of Diagenesis, Vol. 26, Scholle, P.A.; Schluger, P.R. (Eds.); SEPM Spec. Pub. Society of Economic Paleontology and Mineralogy: Tulsa, Oklahoma, USA; 1979; pp 141-157.

32. Kantorowicz, J.D. Sedimen. 1985, 32, 833.

33. Robertson Research International Limited. A Review of the Hydrocarbon Potential of $N$. Ireland, N. Ireland Geological Survey: Belfast, UK; 1987; Enclosure 5. 